\title{
ANÁLISE DO PROCESSO DE ESCAVAÇÃO DE TÚNEIS PELA ÓTICA DO NEW AUSTRIAN TUNNELING METHOD - NATM
}

\section{ARTIGO ORIGINAL}

ESTANQUEIRO, Lucas de Araujo ${ }^{1}$

SALVI, Levi ${ }^{2}$

ESTANQUEIRO, Lucas de Araujo. SALVI, Levi. Análise do processo de escavação de túneis pela ótica do New Austrian Tunneling Method - NATM. Revista Científica Multidisciplinar Núcleo do Conhecimento. Ano 05, Ed. 05, Vol. 12, pp. 75 117. Maio de 2020. ISSN: 2448-0959, Link de acesso:

\section{RESUMO}

A escolha do método para escavação de túneis é determinada pelo projeto de traçado e pelo tipo de solo ou rocha encontrados em cada região. No entanto, o método de escavação está ligado diretamente a velocidade desejada para execução do serviço e ao tipo de solo. Esses dois fatores regem o estudo de viabilidade, porque o método mais rápido dificilmente será o mais econômico e sustentável. A escolha equivocada do método poderá acarretar uma manutenção mais onerosa para o projeto na sua totalidade, que engloba a execução, acabamento e manutenção. Este artigo avaliou e compilou as características do "New Austrian Tunneling Method" (NATM), tal como suas etapas de execução e aplicação prática, resultando em uma análise que demonstra ser uma alternativa eficiente, sustentável e economicamente viável na construção de túneis, primordialmente rodoviários e ferroviários, posto que o cenário nacional tem grande potencial de crescimento no segmento de infraestrutura de transporte.

\footnotetext{
${ }^{1}$ Graduando em Engenharia Civil.

2 Doutor em Engenharia.
} 
Palavras-chave: NATM, túnel, escavação, TBM, estrada, cambota, enfilagem.

\section{INTRODUÇÃO}

Os túneis são construções que acompanharam de forma cronológica e direta o desenvolvimento da humanidade. Conforme Mascarenhas (2014), os túneis são uma das obras mais antigas realizadas pelo ser humano. Segundo Travagin (2012) muito antes da eclosão demográfica na época da Revolução Industrial, com um movimento muito grande entre o campo e grandes centros, os túneis foram obras de engenharia capazes de resolver muitos problemas da época. Moreira (2006) cita a existência de indícios em civilizações antigas que revelam a utilização de obras subterrâneas para a construção de tumbas, canais de irrigação e minas a partir do Período da Pedra Polida, além de obras da Roma Antiga em túneis para condução de esgoto e de abastecimento de água, o que configura uma evolução dos povos antigos a partir do desenvolvimento de obras de engenharia. Com a relação profunda entre quesitos técnicos e econômicos, aos quais são somadas as questões de segurança e meio ambiente, emergiu a necessidade de tratar tais obras subterrâneas com maior rigor científico e tecnológico. Isto acabou resultando em uma mudança na filosofia de construção de túneis, que deixou de ter um caráter meramente empírico para assumir características mais analíticas e quantitativas (TRAVAGIN, 2012).

Nas últimas décadas o Brasil tem passado por um crescimento populacional de forma a mudar a demografia de suas grandes cidades, com uma grande parcela desse fenômeno devido ao êxodo rural. O desenvolvimento da infraestrutura subterrânea se mostra uma boa solução para se vencer uma superfície já saturada de meios de transporte e os altos relevos criados pelos maciços presentes em todo o território brasileiro. Atualmente, é possível contemplar por dados estatísticos que, de todo o volume de escavações subterrâneas civis em todo o mundo, cerca de noventa porcento é voltada para a construção de túneis (MONTICELI E OLIVEIRA, 2018) e no Brasil é seguido o mesmo padrão.

O New Austrian Tunneling Method (NATM) não é um método novo e já vem sendo observado desde a década de 1960. Este nome, inclusive, foi dado para diferenciá-lo 
de outros métodos. O método também foi conhecido como Método de Escavação Sequencial e Método de Revestimento de Concreto Projetado.

O NATM é o método convencional mais difundido pelo mundo, e o preferido no Brasil. Segundo Monticelli e Oliveira (2018), ele é definido como o método em que o maciço do entorno da seção do túnel é integrado ao seu suporte, formando um grande anel fechado. Essa estrutura é feita a partir de concreto projetado e quando existe necessidade, se utiliza também cambotas metálicas, tal como tirantes e enfilagens. A escavação é realizada a partir de explosivos, sendo a detonação dos mesmos feita de maneira controlada, e permite desagregar desde solos até rochas sãs.

Estudos geológicos ditam o avanço das escavações de cada frente de serviço. Tal estudo é mais conhecido como método "Rock Mass Rating" (RMR), que na tradução direta remete a "Classificação da Massa Rochosa", desenvolvido por Bieniawski Z.T. Também foi avaliado o método de Rock Mass Quality (Índice Q), desenvolvido por Barton N, que auxiliará no entendimento da classificação dos maciços rochosos.

A Figura 1 mostra a área de tensão em uma estrutura de suporte convencional rígido e a área de distribuição de tensões na estrutura de suporte do método, formando uma zona plástica com alívio de tensão e, corroborando para um menor risco de desmoronamento do maciço.

Até o momento não foi identificada norma da Associação Brasileira de Normas Técnicas (ABNT) para o NATM em relação a construção. As normas encontradas que se referem à túneis são as normas ABNT NBR 15981/2011 - "Sistemas de segurança contra incêndio em túneis - Sistemas de sinalização e de comunicação de emergências em túneis", a ABNT NBR 15775/2009 - "Sistemas de segurança contra incêndio em túneis - Ensaios, comissionamento e inspeções" e a ABNT NBR 5181/2013 - "Sistemas de iluminação de túneis - Requisitos". Estas normas não auxiliam na etapa da escavação. 
Figura 1 - Revestimento do método NATM indicando a área de tensão

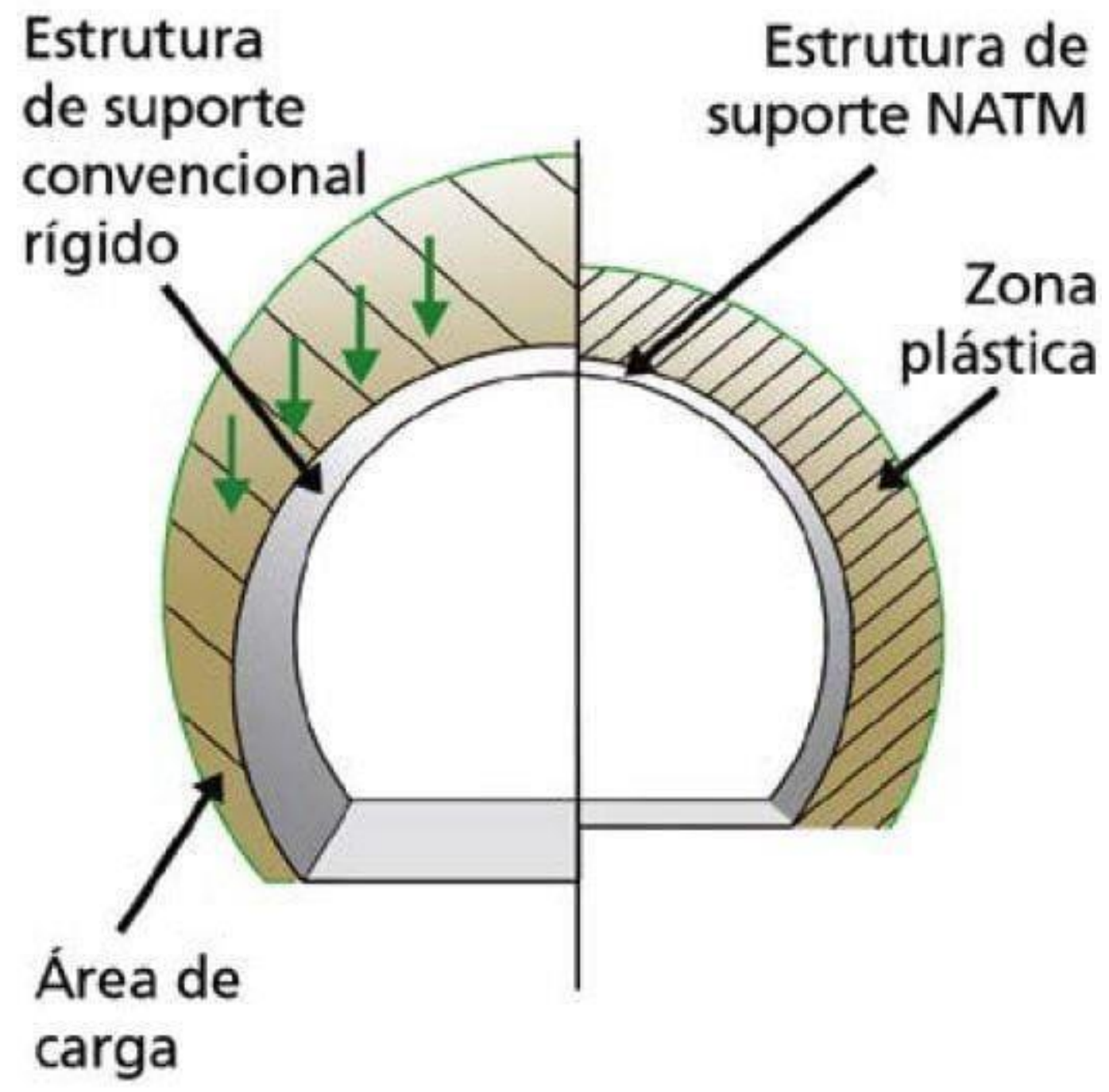

Fonte: Solotrat - Engenharia Geotécnica LTDA, 2018

\subsection{HISTÓRICO}

Segundo Moreira (2006), as escavações de túneis se iniciaram nos primórdios da civilização, antes mesmo do desenvolvimento de explosivos e equipamentos mecanizados de escavação. A construção era realizada por operários que escavavam com ferramentas manuais os maciços a serem percorridos. Os primeiros indícios de construções de túneis, datam da época Medieval, da qual existem registros de túneis desenvolvidos para o abastecimento de água e esgoto. Na figura 2 pode ser visto a Cloaca Massima, que é um dos túneis mais antigos e famosos da história, que se 
localiza na Itália e foi desenvolvido pelo Império Romano com 3,2 metros de largura e 4,2 metros de altura. As dimensões são grandiosas se considerado o período em que foi construído.

Segundo Assis (2002), o túnel mais antigo sobre o qual existe registro foi construído na Babilônia, a cerca de 4.000 anos, abaixo do leito do rio Eufrates com o objetivo de fazer a ligação entre um palácio e um templo da região. Na Grécia também, há 1.800 anos, túneis foram construídos para o transporte de água e são utilizados até hoje.

No início os túneis foram utilizados para o transporte água, como no Império Romano, mas o uso foi ampliado como na passagem de ferroviárias, no acesso a minas de minérios e nos canais de navegação. Nos anos atuais são muito utilizados para passagens rodoviárias.

Figura 2 - Túnel Cloaca Massima

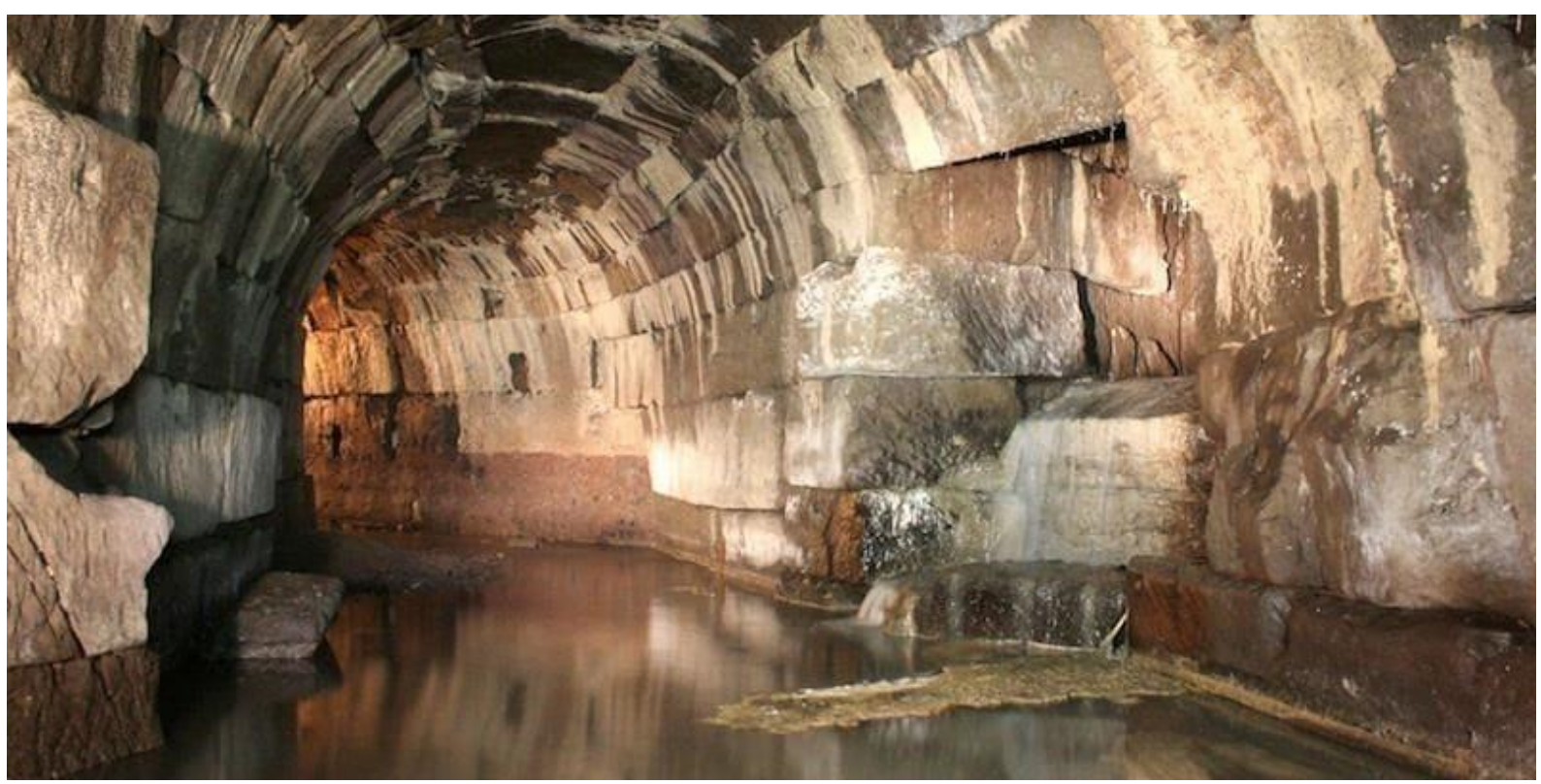

Fonte: https://www.zonzofox.com/roma

No Brasil, com o uso de explosivos, mais especificamente a dinamite, a indústria tuneleira se desenvolveu em meados do século XIX, com uso principalmente em rochas e os primeiros túneis ferroviários foram construídos por volta de 1860. O marco foi a Estrada de Ferro Dom Pedro II, localizada na Serra do Mar no Estado do Rio de 
Janeiro (Rocha, 2012), com o maior túnel na época de 2.236 metros de extensão, aberto em 1864.

Segundo Rocha (2012), o crescimento significativo de obras de túneis no país vem ocorrendo nas últimas décadas. Em pesquisa, o Comitê Brasileiro de Túneis (CBT) levantou que o volume total construído até a década de 1990 era inferior a $4.000 .000 \mathrm{~m}^{3}$. Cinco anos depois, esse valor saltou para mais de $11.000 .000 \mathrm{~m}^{3}$, uma taxa de crescimento proporcional próxima de $500 \%$, algo bem significativo em termos de desenvolvimento de infraestrutura.

O NATM chegou ao Brasil na década de 1970, e foi implementado na construção da Ferrovia do Aço entre a cidade do Rio de Janeiro e cidade de Belo Horizonte. Atualmente, é o método mais utilizado para a construção de túneis no país, ao lado do método mecanizado, popularmente conhecido como TBM.

\subsection{BENEFÍCIOS DO NATM}

O NATM é caracterizado mundialmente por sua versatilidade, segundo a Associação Mundial de Túneis e Espaços Subterrâneos (ITACET), porque independe da extensão total do túnel, sua escavação pode adquirir diferentes formas e múltiplas frentes de avanço, acentuando assim a sua flexibilidade. A implementação permite adaptação variável às condições geológicas existentes na região e é possível que se faça intervenção em toda área da escavação, uma vez que o método é cíclico. Então, caso ocorra um imprevisto, uma medida pode ser facilmente adotada. Não obstante, o acesso livre e fácil à frente de escavação, facilita o acesso de equipamentos e de pessoal, tal como qualquer atividade intrínseca à obra.

\subsection{DESAFIOS DO NATM}

Ao encontrar maciços heterogêneos com diversas classificações de rochas, o NATM encontrará desafios geológicos e geotécnicos e a escavação deverá ser parcializada, reduzindo o avanço, devido ao cuidado necessário no tratamento por conta da maior instabilidade, e suporte aplicado a cada ciclo de escavação. Rochas brandas têm uma 
maior probabilidade de apresentar zonas de falhas e planos de ruptura, o que aumenta as chances de desmoronamento e diminui o tempo de auto suporte do maciço, obrigando uma intervenção rápida e por vezes personalizada para cada trecho escavado, atrasando o processo. A Figura 3 demonstra em um diagrama a relação do tamanho do vão e o tempo de auto suporte de acordo com a classe da rocha encontrada.

Figura 3 - Tempo de auto suporte de acordo com a classe da rocha.

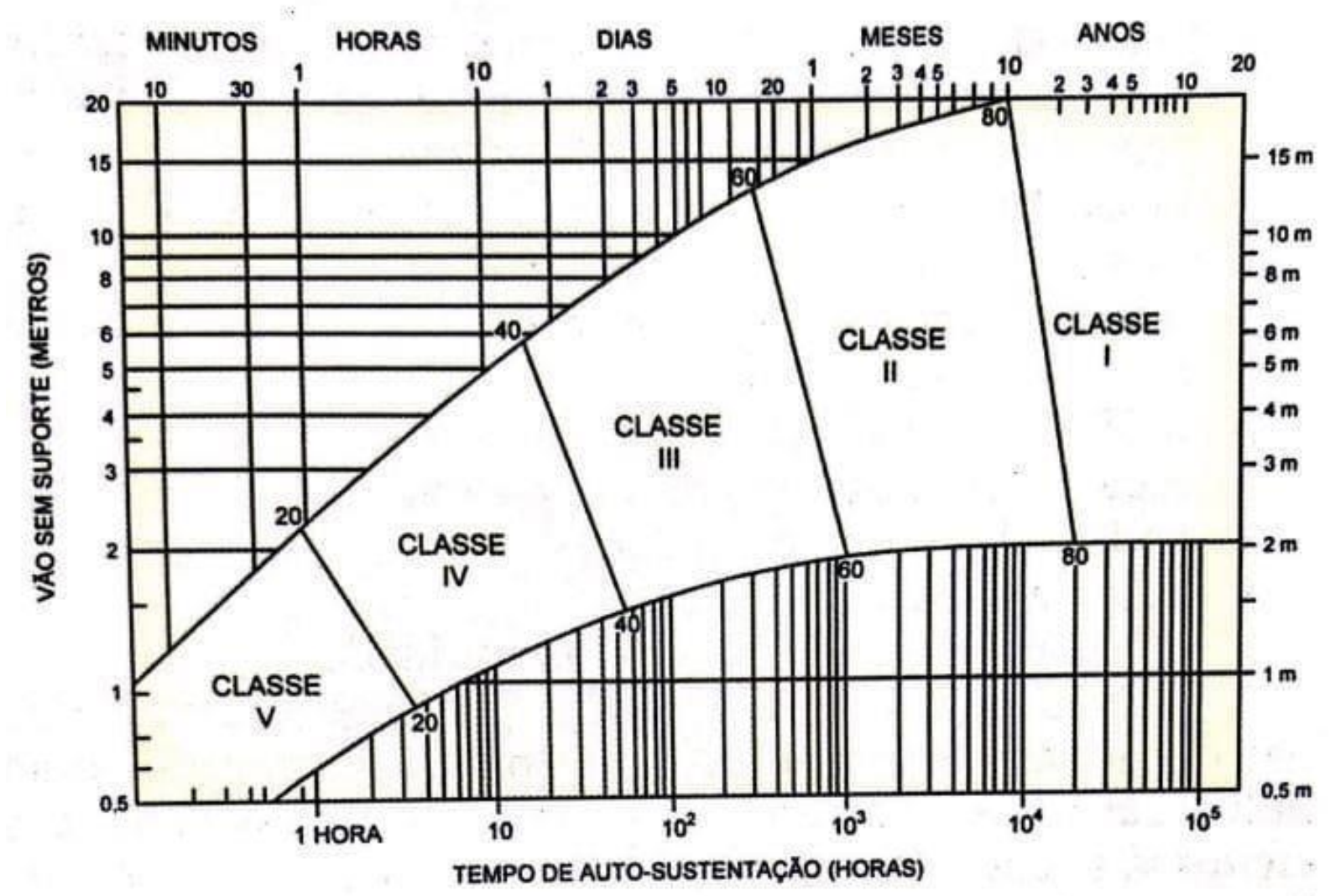

Fonte: Bieniawski (1974).

Para Monticeli e Oliveira (2018), além da classificação das rochas, a área da seção transversal do túnel, como na Figura 4, também representa um desafio para o NATM. Geralmente, seções com mais de $100 \mathrm{~m}^{2}$ necessitam ser parcializadas, visando um maior tempo de auto suporte do maciço. A escavação restante pode ser realizada em bancada com perfuração vertical. 
Figura 4 - Modelos de parcialização da seção transversal.

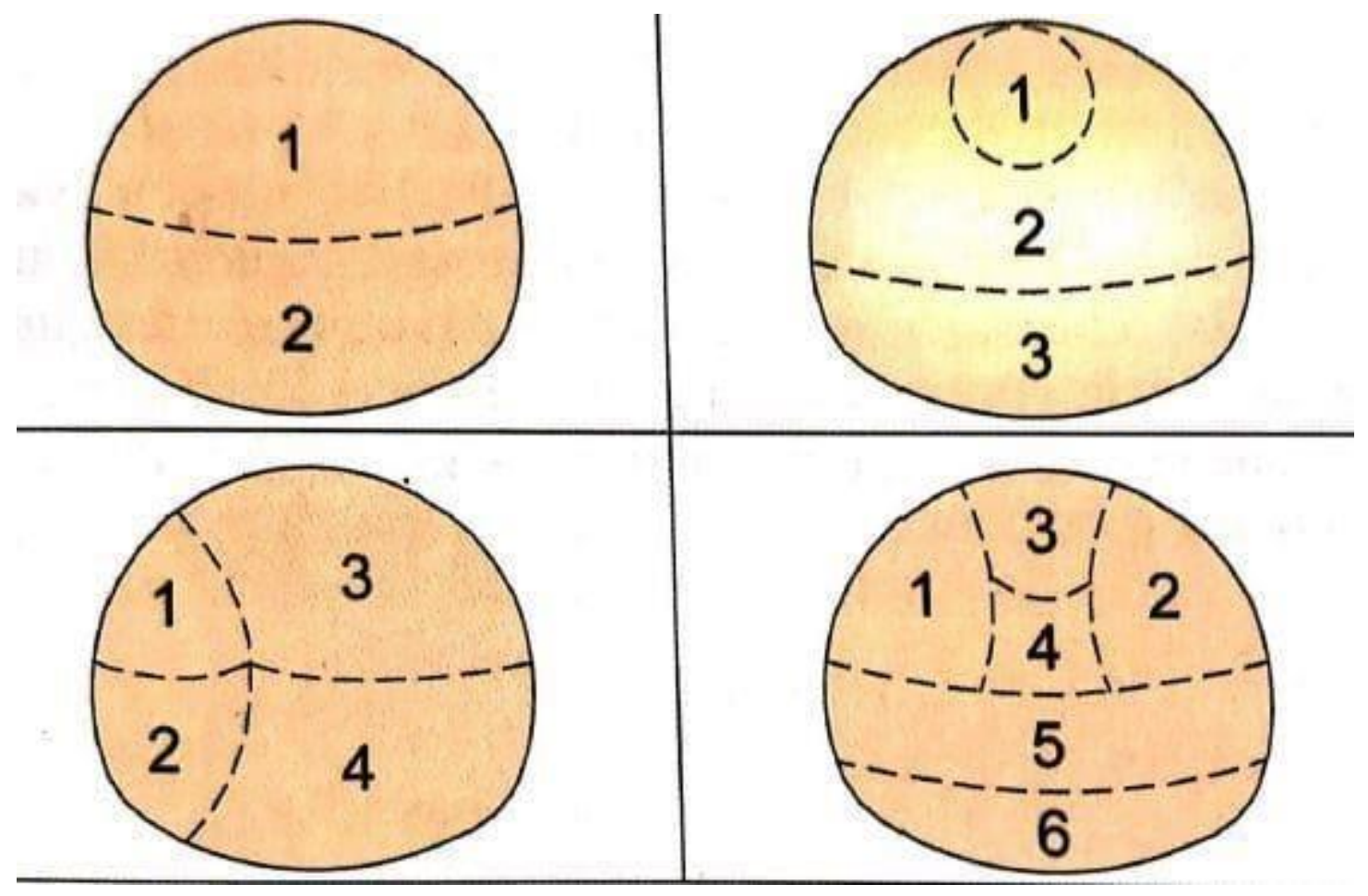

Fonte: Monticeli e Oliveira (2018).

\subsection{COMPARANDO NATM E TUNNEL BORING MACHINE(TBM)}

O TBM é um método de escavações mecanizada para desenvolvimento de túneis, que na indústria de infraestrutura é um concorrente do NATM. O TBM consiste basicamente em uma escavação mecanizada com a utilização de máquinas tuneladoras. O ponto forte do TBM é à velocidade de escavação, pois o equipamento permite escavar e montar os anéis de suporte do maciço ao mesmo tempo. Uma obra famosa no Brasil realizada pelo TBM foi a ampliação do metrô na cidade do Rio de Janeiro, como aparece na Figura 5, com aproximadamente de 120 metros de comprimento.

O equipamento escava através de uma cabeça de corte (cutter head) adaptável a cada tipo de solo ou rocha, equipada com discos e lâminas de corte feitas de aço diamantados de alta resistência. Esse elemento, assim como todo o equipamento, possui dimensão exata do diâmetro do túnel a ser escavado. $O$ avanço é dado através 
de cilindros hidráulicos, que apoiados em sua couraça de revestimento, empurram a cabeça de corte em direção a seção a ser escavada. À medida que o equipamento avança, o maciço é revestido com concreto e cambotas metálicas, formando aletas, que também são chamadas de couraças, sendo utilizados geralmente em maciços com um poder de auto suporte baixo.

Segundo a ITACET, o TBM é limitado à seção circular e requer uma maior área no canteiro para o equipamento da tuneladora, podendo alcançar extensões maiores que 100 metros de comprimento, o que é um fator limitante para muitos empreendimentos.

Figura 5 - Escavação da linha 4 do Metrô do Rio de Janeiro a partir do método TBM.

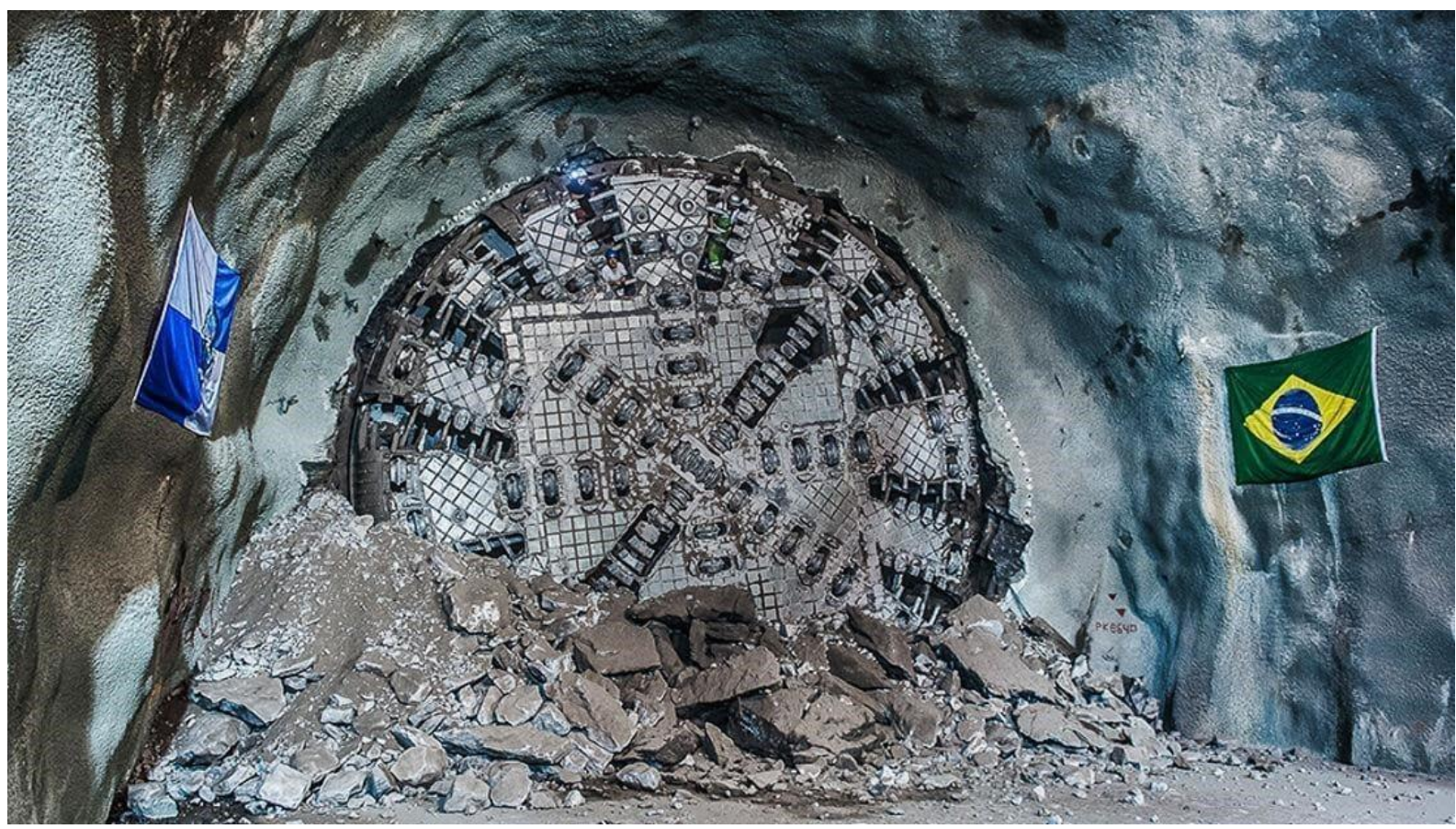

Fonte: divulgação Herrenknecht - "Tunnelling Systems".

Sauer (2003) faz um comparativo entre a utilização de cada método definindo como parâmetro a extensão do túnel, conforme a Figura 6. Uma grande desvantagem do TBM se apresenta em túneis com extensões iguais ou inferiores a 1,6 km de extensão e a partir de $3,2 \mathrm{~km}$ o TBM e NATM têm custos semelhantes. 
Figura 6 - NATM e TBM sendo comparados a partir de dois parâmetros: extensão e custo.

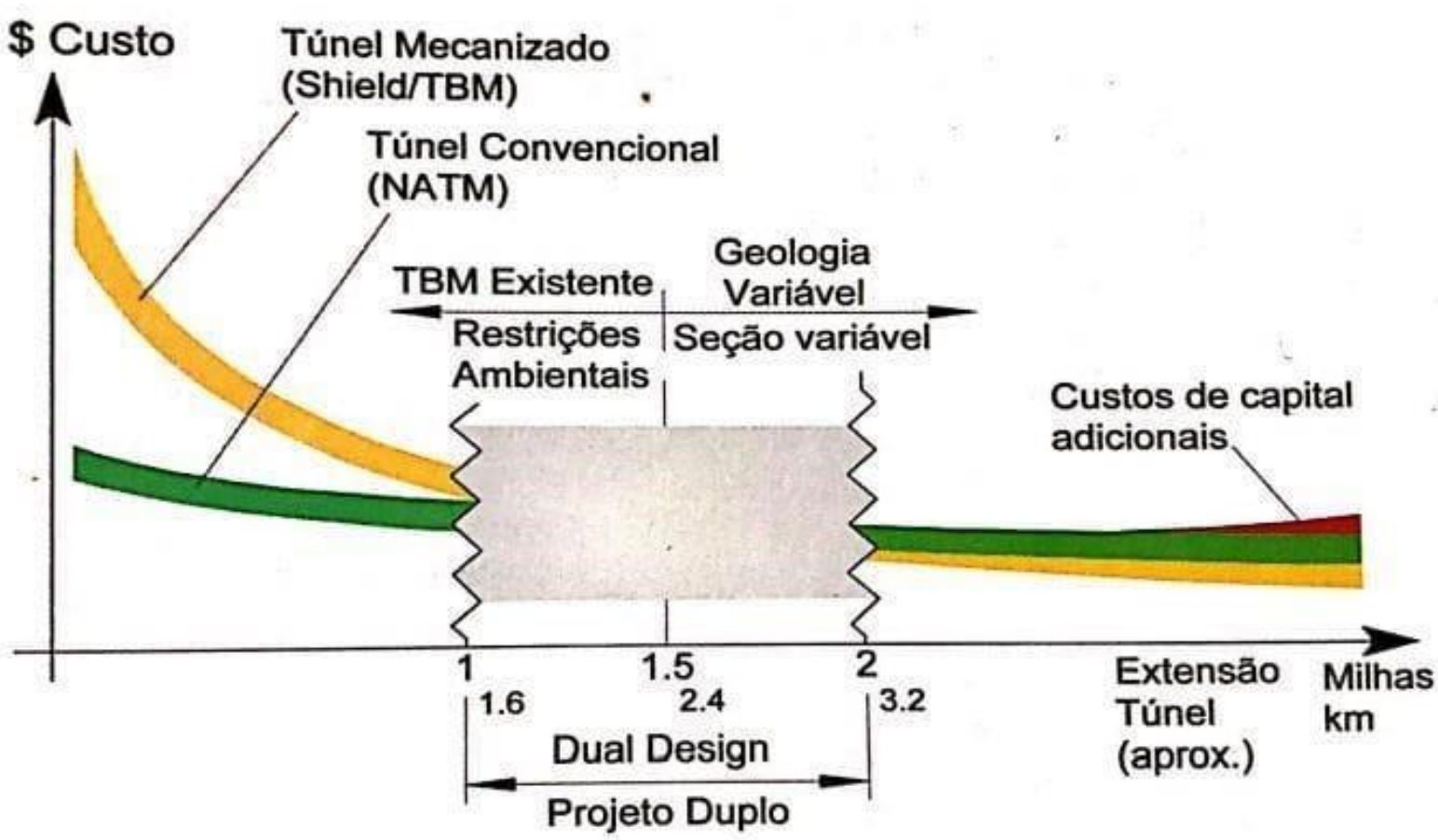

Fonte: Sauer (2003).

Empreendimentos de grande porte atuais trazem à luz a diferença de custo em relação a cada método. A Concessionária CONCER, que administra a estrada entre Rio de Janeiro RJ e Juiz de Fora MG, realizou um estudo de viabilidade para a construção de um túnel rodoviário na rodovia BR-040, mais especificamente no trecho da serra de Petrópolis-RJ, e realizou um comparativo entre duas obras subterrâneas: a primeira é a ampliação da Rodovia dos Tamoios no Estado de São Paulo e a Linha 4 do Metrô da cidade do Rio de Janeiro RJ. Seguindo a tabela de preços unitários da época (2.013), a obra da Rodovia dos Tamoios com aproximadamente 13 quilômetros de túneis a serem construídos com a utilização do NATM chegava a um valor de custo de $R \$ 2,3$ bi, o que daria um valor de $R \$ 176,9$ mi por quilômetro construído, um alto custo à primeira vista. A obra do metrô do Rio de Janeiro, realizada a partir do método mecanizado TBM, com cerca de 16 quilômetros subterrâneos de extensão, possuía um valor à época de $R \$ 8,5 \mathrm{bi}$, o que remete a um valor aproximado de $R \$ 500 \mathrm{mi}$ por quilômetro construído, mostrando que de fato, o método mecanizado atinge valores 
muito mais altos que o método de escavação a fogo. Outro fator determinante nesse comparativo entre os métodos é o Índice $Q$, que é a classificação proposta por Barton, Lien e Lunde, (1974), onde se relaciona o tamanho dos blocos, a resistência ao corte e a tensão efetiva, basicamente indicando um valor relativo da resistência e dureza do maciço. Valores para o Índice $Q$ próximos de 80 dão vantagem para o método de escavação à fogo, se for analisada a produtividade em relação a rochas mais duras, como pode ser visto na Figura 7.

Figura 7 - Comparativo de acordo com o índice Q.

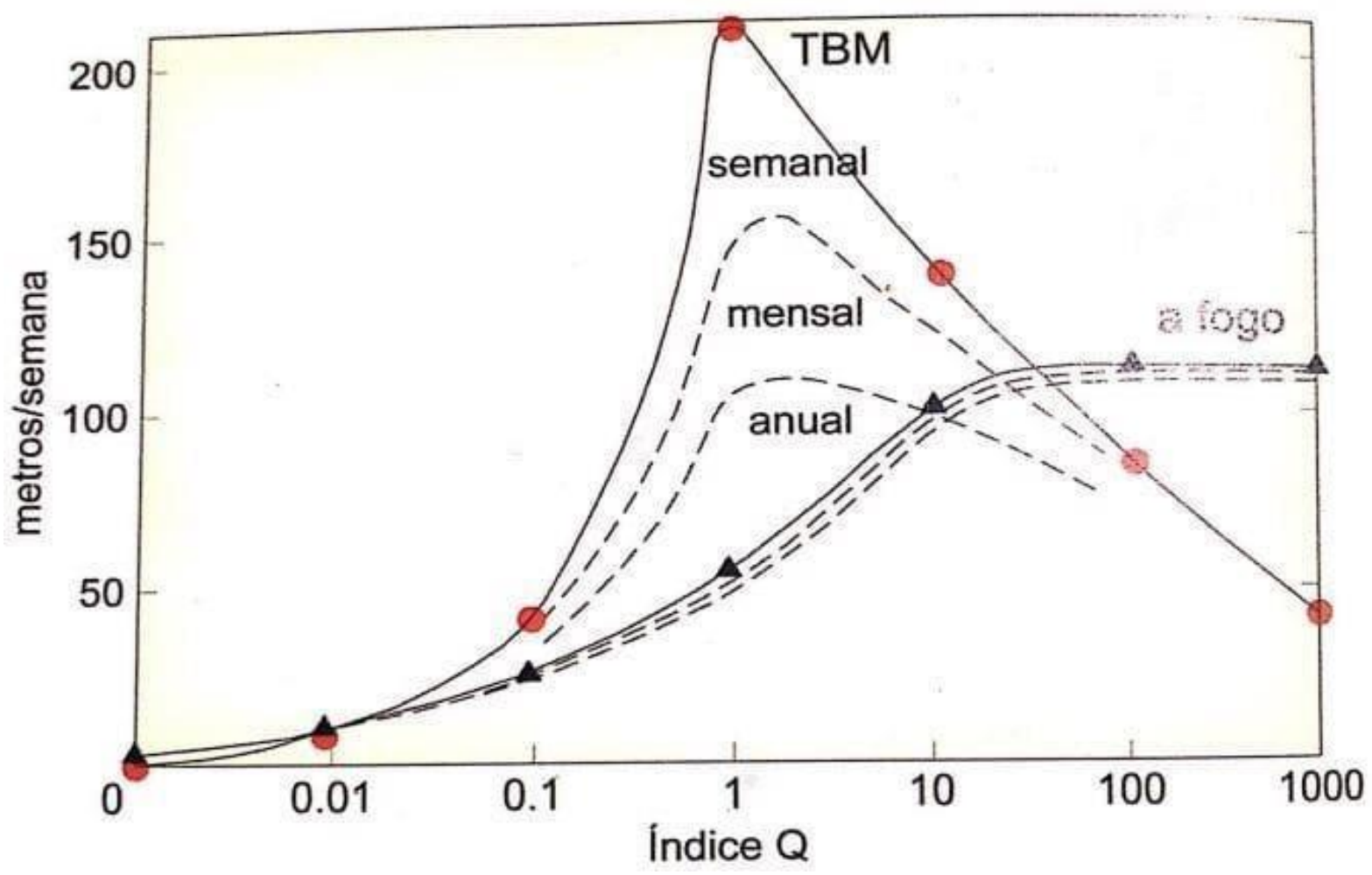

Fonte: Barton (2000).

\section{METODOLOGIA NATM}

\subsection{ETAPAS DO PROJETO}

O projeto para um empreendimento subterrâneo é complexo e envolve diversos dados a serem indexados, como os aspectos legais, econômicos, operacionais, de segurança, geológicos e geotécnicos, tecnológicos, ambientais e construtivos. 


\subsubsection{LEVANTAMENTO DO TERRENO}

O relevo é o principal parâmetro a ser analisado na construção de uma estrada, seja ela rodoviária ou ferroviária. O relevo depende diretamente da natureza das rochas encontradas na região, que a partir de processos físicos e químicos, conhecidos popularmente como intemperismo, também deram origem ao solo da área. A classificação do relevo é calcada na topografia do terreno e nos tipos de solos, fatores que estão ligados diretamente à geologia, geomorfologia e clima (MONTICELI E OLIVEIRA, 2018).

Projetos de estradas rodoviárias são baseados no levantamento topográfico de toda a região da estrada a ser construída, e principalmente onde irão se localizar os túneis. No anteprojeto, é comum serem evitados os pontos críticos como vilarejos, grandes cursos d'água e obras já realizadas, porque são pontos que além de impor dificuldades na execução, também a prolongarão. Os túneis serão posicionados nas grandes diferenças de cota do terreno, a fim de se vencer grandes aclives e declives.

\subsubsection{INVESTIGAÇÃO GEOLÓGICA}

Após o levantamento topográfico e identificação dos maciços e pontos críticos é necessário dar mais precisão ao traçado do projeto a partir de estudos das condições geológicas e geotécnicas. Os pontos positivos e negativos são avaliados, de forma econômica e técnica até convergirem para uma melhor solução. Imagens da superfície da Terra visando a coleta de dados do meio físico, são uma prática utilizada desde a década de 1930 e podem ser obtidas por fotografia aérea, sensoriamento remoto e imagens orbitais. A leitura dessas imagens é um recurso imperativo para o trabalho de mapeamento geológico. A elaboração deste mapa fotogeológico, envolve o reconhecimento dos alinhamentos, morfologia do relevo, quebras topográficas e zonas homogêneas (RICCI E PETRI, 1965). Para Monticeli e Tressoldi (2013), existem três maneiras de se analisar uma superfície de acordo com o tipo de ação do investigador. Há o método indireto, no qual o investigador não possui contato físico com o material a ser avaliado, identificando remotamente as propriedades físicas, e o método direto, em que o investigador tem contato físico com o material a ser estudado 
através de escavações. Existe ainda o método semidireto, onde o investigador não tem contato com o material na profundidade em que ele se encontra, mas o contato se dá por meio de amostras obtidas em sondagens. Para uma boa investigação geológica, o contato do investigador com o material, ainda que semidireto, é importante para avaliação de suas condições reais. Na Figura 8, é demonstrado um tipo de investigação mecânica para a caracterização geológica-geotécnica de um terreno. Podendo perfurar qualquer tipo de rocha, em qualquer inclinação, a sondagem rotativa alcança elevadas profundidades, sendo comumente escolhida para estudos mais detalhados. O conjunto mecanizado dessa sondagem possui uma peça cortante de alta dureza, responsável pelo corte de qualquer tipo de rocha a partir de movimentos de rotação. Possui em seu corpo também um tubo livre que preserva o testemunho do material perfurado. O testemunho é a amostra cilíndrica da rocha extraída que permite caracterizar o maciço, sendo possível visualizar até zonas de transição de classes de rochas e falhas, na avaliação desse procedimento em um determinado perímetro.

Figura 8 - Desenho esquemático de uma estrutura montada para uma sondagem rotativa.

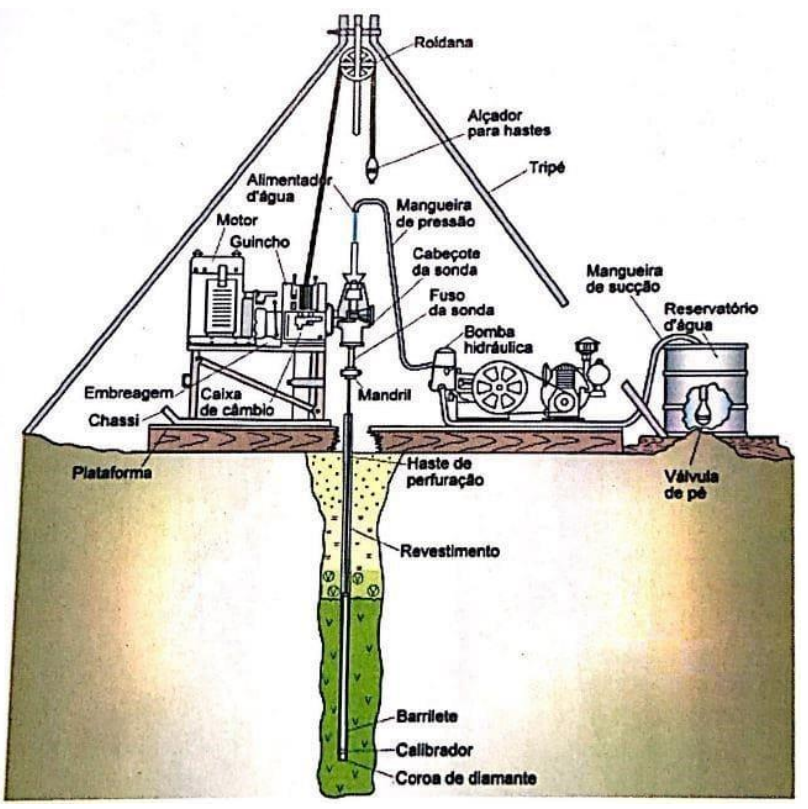

Fonte: Indústria e Comércio de Equipamentos para Mineração e Sondagem. 
A investigação geológica e geotécnica mais detalhada dá maior segurança nas tomadas de decisões para os desafios que serão encontrados ao decorrer da obra, além de fornecerem dados pertinentes às diversas fases do empreendimento que serão condicionantes a cada ação a ser tomada. Nesta fase, são levantadas informações que serão úteis durante todo o projeto, e normalmente é o momento em que se define se o NATM será utilizado.

\subsubsection{ANÁLISE DE RISCOS}

Com o auxílio da investigação geológica, é possível caracterizar um maciço e definir sua complexidade, identificando não só o tipo de rocha e solo presentes, como possíveis falhas geológicas, que podem se classificar como falha com evidência e falha comprovada. Essas falhas são fraturas encontradas nos blocos rochosos que representam uma possível área de desabamento, o que infere a especificação de um tratamento imediato, porque o tempo de auto suporte é curto.

Quando se constrói perto de áreas urbanas, é preciso também analisar os riscos que a execução dos túneis trará para a população do entorno. Como o desmonte de rocha é feito à fogo, é necessário certificar-se de que a área da frente de escavação estará bem isolada, e que os tremores causados pela explosão não irão abalar as casas nas proximidades, evitando perturbações nas fundações.

A análise de riscos não se resume apenas ao início do projeto, mas se renova durante toda a realização do projeto por meio de um mecanismo importante do empreendimento chamado Acompanhamento Técnico de Obra (ATO). Segundo Rabcewicz (1975), este é um processo fundamental na implantação de obras subterrâneas e se resume no acompanhamento contínuo do avanço das escavações e como o maciço e as estruturas no entorno da obra estão se comportando. Este serviço requer uma interface adequada entre projeto e execução, pois é a partir do cruzamento destes dados levantados que será possível realizar modificações no projeto de acordo com o constatado na obra, a fim de eliminar cada vez mais os riscos de acidentes e contratempos no empreendimento. 


\subsubsection{DEFINIÇÃO DA FORMA DA SEÇÃO TRANSVERSAL}

A forma da seção transversal dos túneis é definida de acordo com o comportamento mecânico dos maciços. Estes, possuem estruturas que refletem duas categorias básicas de comportamento de deformação: o comportamento rúptil (ou frágil, quando os processos de fragmentação das rochas prevalecem); e o comportamento dúctil, quando não se desenvolvem descontinuidades e prevalece o fluxo, por exemplo, no caso de dobras. Os fatores que comandam esses comportamentos são a temperatura e a pressão que existem em função da condição confinante da rocha, da profundidade, presença de fluidos e tempo de atuação das tensões. Entre 10 e $15 \mathrm{~km}$ de profundidade acontece o comportamento dúctil. Já o comportamento rúptil, acontece no limiar de até $4 \mathrm{~km}$ de profundidade. Por isso, apenas o segundo comportamento fora analisado, uma vez que obras subterrâneas de túneis são raras de acontecer além dessa profundidade.

O comportamento rúptil é definido por critérios de ruptura, onde o mais utilizado é o Critério de Mohr-Coulomb. Ele infere que a tensão cisalhante $(\sigma c)$, fator que provoca a ruptura em um plano submetido a uma tensão normal ( $\sigma n)$, depende da coesão (c) e do coeficiente de atrito, definido pela tangente do ângulo de atrito $(\Psi)$. Os dois últimos parâmetros, coesão e ângulo de atrito são definidos de acordo com a classificação da rocha e as características intrínsecas ao seu material, que podem ser identificadas por ensaios laboratoriais. Então pelo critério de ruptura de MohrCoulomb, pode-se obter a tensão cisalhante, que é fator essencial na determinação do comportamento mecânico do maciço:

\section{$\sigma_{c}=c+\tan (\Psi) \cdot \sigma_{n}$}

Existem também critérios de ruptura com outras inferências, já que, o critério de MohrCoulomb, por exemplo, falha ao explicar a resistência à tração, que se mostra até dez vezes menor quando analisada em laboratório do que a prevista no modelo. Outros modelos utilizados são: o Critério de Ruptura de Griffith e o Critério de Ruptura de Von Mises, que podem ser consultados em literatura específica. 
A combinação desses três critérios, no entanto, permite realizar uma boa avaliação do comportamento da rocha, gerando o Diagrama de Mohr, como é possível analisar na Figura 9. Os três modelos combinados, se localizam no Diagrama onde melhor representam a realidade da deformação das rochas.

Esse estado de tensão dos maciços é diretamente relacionado na avaliação da integridade e segurança nas obras subterrâneas, pois este estado é perturbado quando uma escavação é executada. Esta atividade induz uma redistribuição de tensões no maciço que se encontra na vizinhança do espaço escavado, gerando um novo estado de tensões, a partir do qual seu tempo de auto suporte é definido. Esse estado de tensões e de auto suporte está diretamente relacionado com o formato escavado que deixa o maciço em face livre para o túnel em questão. Por esse motivo, seções arredondadas são comuns em obras de túneis, já que por meio de sua geometria, o maciço redistribui melhor suas tensões, principalmente de compressão, e é possível aproveitar ao máximo a capacidade autoportante, adjacente ao contorno escavado.

Figura 9 - Critérios combinados, formando o Diagrama de Mohr para análise de deformação das rochas.

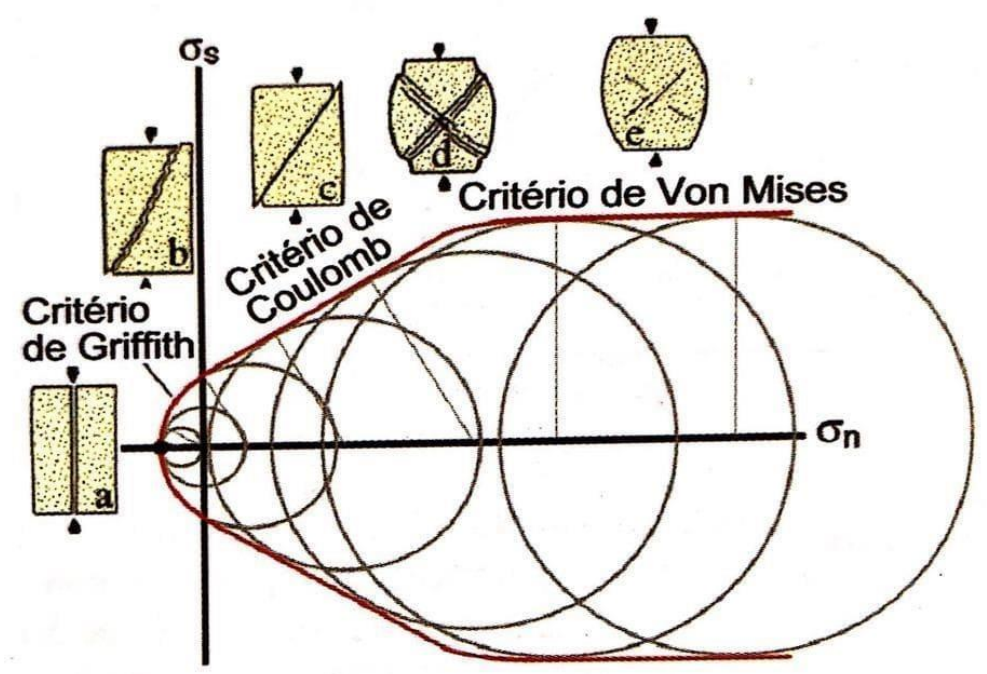

Fonte: Fossen (2012). 
Dependendo da classificação do maciço, a seção plena a ser escavada pode ficar instável, não deixando tempo suficiente de auto suporte para que o tratamento primário seja realizado. Isto acontece primordialmente em seções acima de $100 \mathrm{~m}^{2}$, quando a área adjacente ao contorno escavado é muito grande e o estado de tensões chega a seu limite de auto suporte. Nestes casos, a escavação pode ser parcializada, visando a diminuição da área a ser escavada, provocando um alívio de tensões, propiciando maior tempo e resistência autoportante. Os tipos de parcialização mais utilizados são a escavação em meia seção e side-drifts - quando a seção é parcializada em quatro partes, e após o túnel ser vazado totalmente no quarto de seção, é feito o devido tratamento do maciço e seção restante é escavada, como observado na Figura 10.

Figura 10 - Modelos de parcialização da seção transversal.

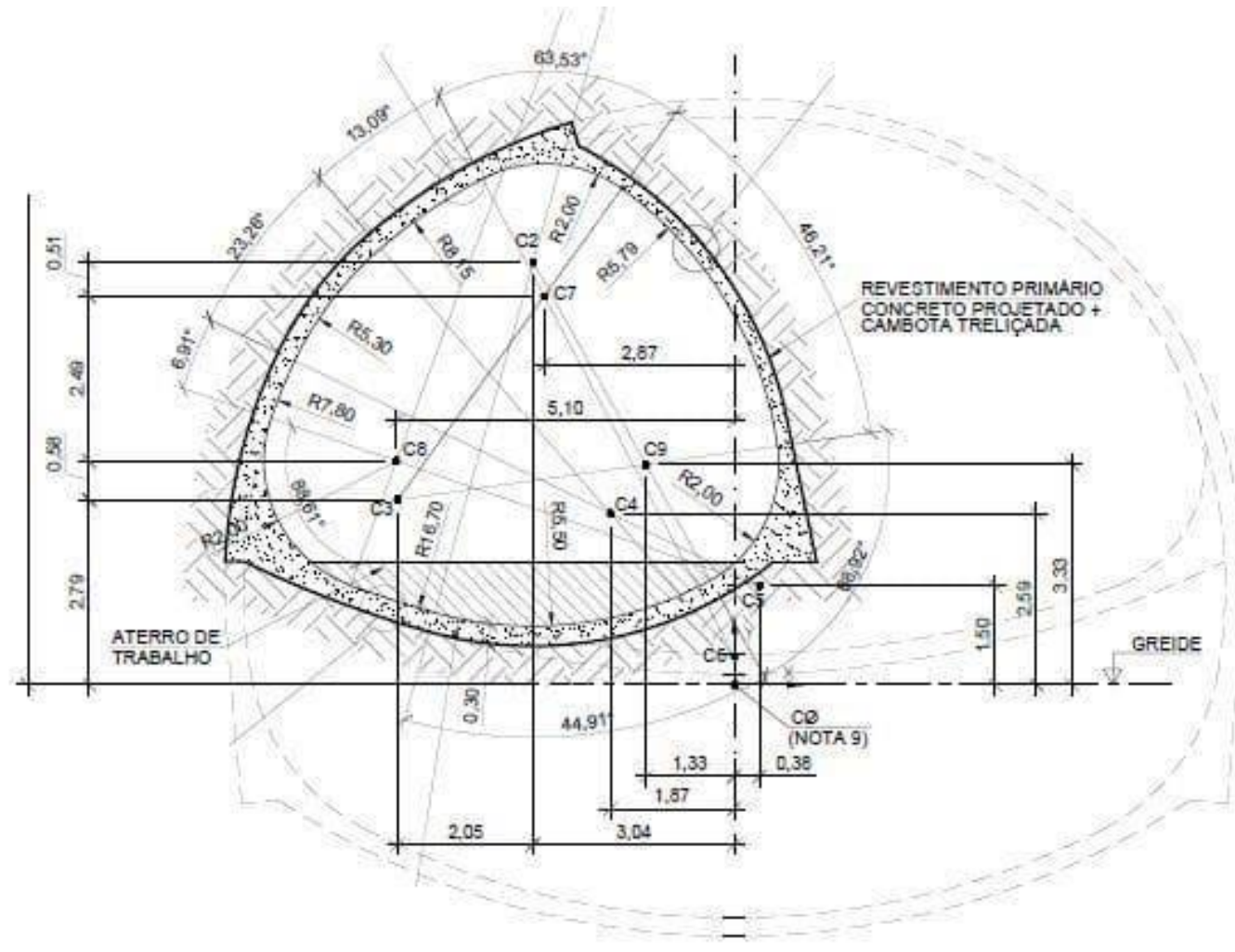

Fonte: Construtora Queiroz Galvão (2019). 


\subsubsection{MÉTODO DE ESCAVAÇÃO E DEFINIÇÃO DE SUPORTE}

a. Plano de Fogo

Em obras subterrâneas, especificamente em túneis, uma boa detonação é tão importante quanto a escolha da forma da seção transversal ou a escolha correta do suporte do maciço. Para uma detonação ser considerada eficaz, é necessário levar em consideração dois fatores de extrema relevância: a explosão deve desagregar a rocha de forma eficiente e econômica, fragmentá-la de tal forma que seja simples de removê-la, transportá-la, armazená-la e processá-la (no caso de reutilização do material desagregado); além disso, o conjunto de rochas ainda restante após a explosão, deve ser danificado minimamente para que o suporte aplicado futuramente não seja dimensionado além do previsto de acordo com a classe da rocha. Na Figura 11 , é possível verificar o efeito de uma má detonação.

Quando um explosivo contido em um furo é detonado, os gases gerados pela explosão impactam diretamente nas paredes do furo devido à alta pressão da detonação, gerando uma intensa onda de pressão que se propaga para o interior da rocha por trincas abertas com este grande impacto. No entorno da parede deste furo, as tensões geralmente extrapolam a resistência máxima da rocha, causando fraturas de forma a desagregá-la. 
Figura 11 - Consequência de uma má detonação. Sobreescavação - overbreak provocando uma deformidade na seção transversal
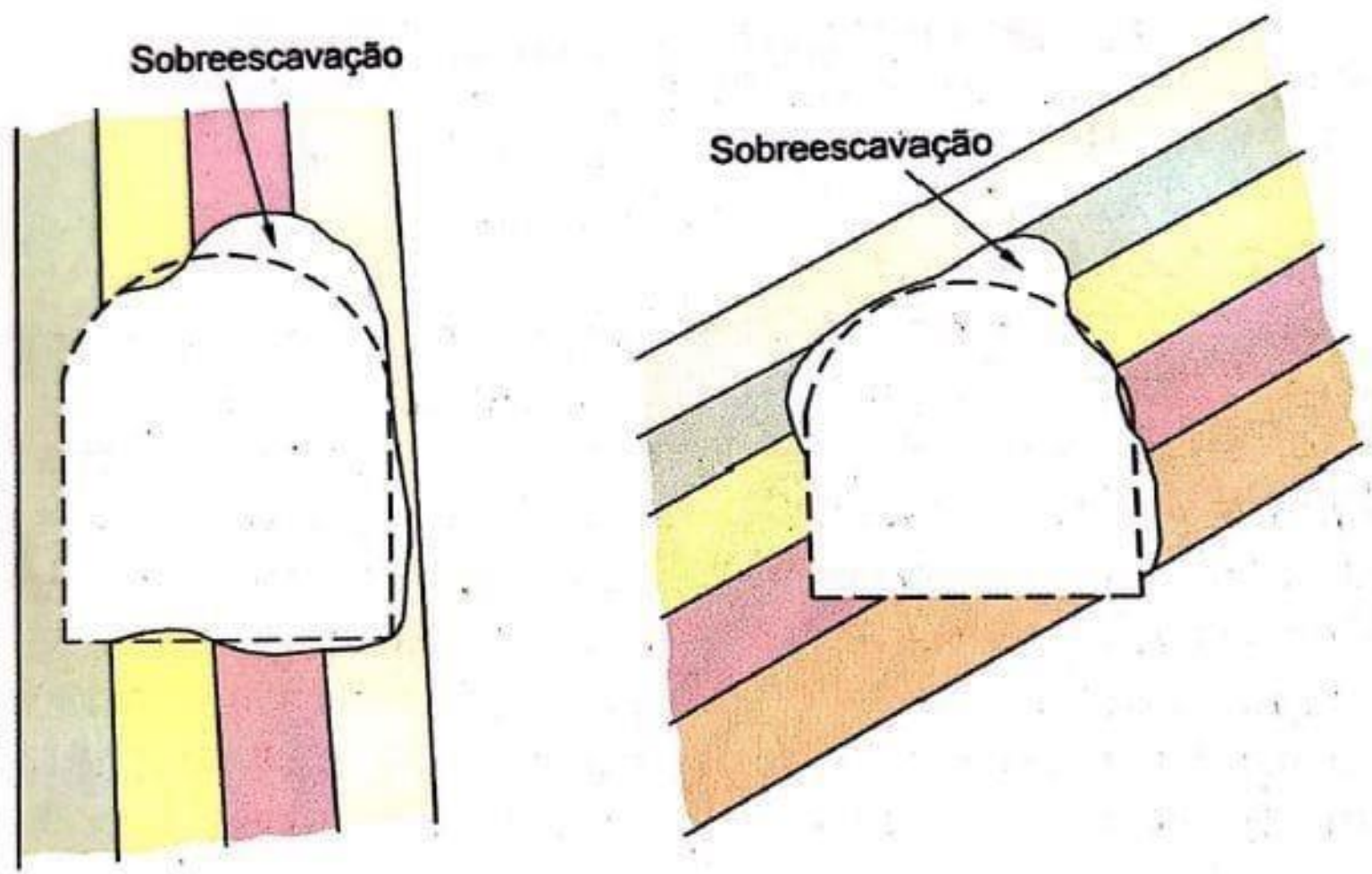

Fonte: Monticeli e Oliveira (2018).

Fora desta zona em que a resistência à compressão da rocha é excedida, uma zona de trincas radiais será formada por uma componente de tensão de tração tangencial do campo de tensão gerado pela explosão. Essas verdadeiras rachaduras radiais continuarão a se propagar radialmente, desde que a tensão de tração tangencial nas pontas da fissura exceda a resistência à tração da rocha, provocando um fenômeno de abertura dessas rachaduras. Em maciços reais, essa quebra será influenciada pelas fissuras já existentes na rocha e pelo estado de tensão da mesma. Na Figura 12, é possível visualizar na zona 1 a perfuração da rocha, na zona 2 a zona pulverizada e na zona 3 as trincas radiais que preferencialmente são paralelas à tensão principal do maciço, também mostrada na figura.

Quando o furo é próximo a uma face livre criada por uma explosão anterior ou por um furo de alívio, geralmente localizado no centro da seção transversal a ser detonada, a 
fratura ao redor do buraco é influenciada de forma muito significativa pela presença dessa face livre. Isso ocorre porque a onda de tensão de compressão radial se movendo para fora, é transformada em uma onda de tensão de tração refletida quando encontra uma superfície livre. Esta onda de tração resultante se move da superfície livre em direção ao furo, causando uma alteração no padrão de rachadura resultante, provocando a quebra da rocha do entorno (HOEK \& BROWN, 1982). Esses furos são carregados de explosivos, que é a fonte de energia adicional que permite criar fraturas nas rochas.

Figura 12 - Esquema idealizado de uma fratura induzida por uma explosão. E a indicação da tensão principal.

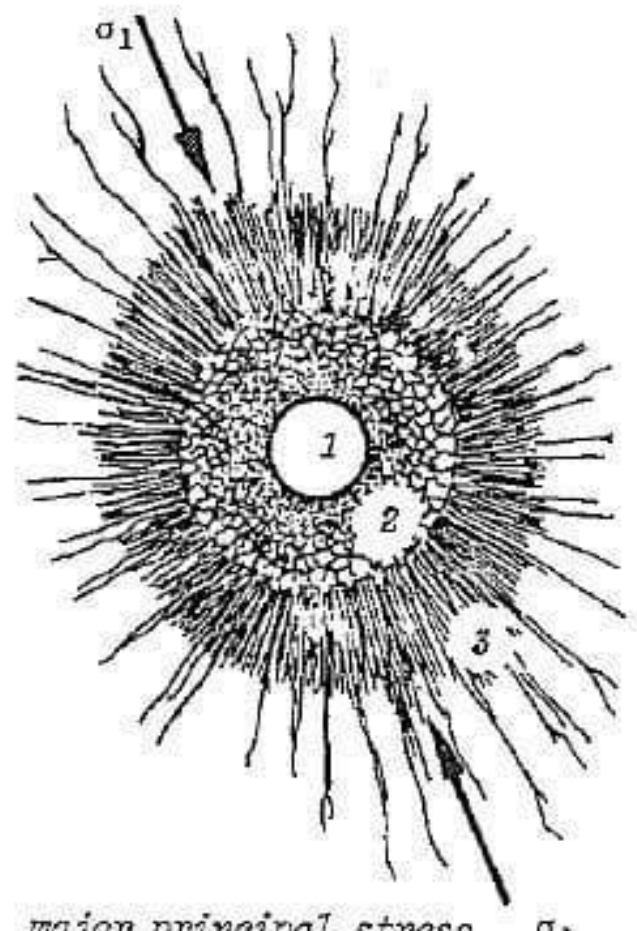

major prinoipal strese $\sigma_{1}$

Fonte: Hoek e Brown (1982).

Para Franco (2014), há três parâmetros muito importantes a serem analisados no que diz respeito aos explosivos: a razão de carga dos explosivos, que é definida pela quantidade de explosivo em gramas necessária para fragmentar $1 \mathrm{~m}^{3}$ de rocha; a velocidade de detonação, caracterizada pela transformação da massa explosiva, em 
torno de $2500 \mathrm{~m} / \mathrm{s}$ a $7000 \mathrm{~m} / \mathrm{s}$; e a densidade, expressa pela razão entre a quantidade de carga explosiva em $1 \mathrm{~m}$ linear de furo.

Os explosivos são escolhidos previamente de acordo com a rocha a se fragmentar em ajuste com esses parâmetros citados anteriormente. Segundo Geraldi (2011), explosivos de alta velocidade e densidade são recomendados para rochas duras, como por exemplo granitos e gnaisses. Já para rochas muito alteradas, que contêm muitas fraturas, explosivos mais lentos e de baixa densidade são os mais recomendados. Existe também os acessórios dos explosivos, que são dispositivos que auxiliam na detonação, gerando energia extra para a mistura ser acionada e iniciar a explosão propriamente dita. São esses, as espoletas comuns, utilizadas em explosões de pequena força para serviços pequenos, e as espoletas elétricas, acionadas por uma corrente elétrica que percorre seu fio, as espoletas não-elétricas. Estas são compostas por um tubo oco de plástico flexível com um diâmetro interno de aproximadamente $1,5 \mathrm{~mm}$ dotado de uma fina camada de material pirotécnico. A partir de uma pequena cápsula explosiva, que pode ser de acionamento mecânico, é gerado um plasma gasoso que em uma velocidade aproximada de $1000 \mathrm{~m} / \mathrm{s}$ percorre o tubo oco até chegar no material detonante. Por último, encontra-se também o cordel detonante, muito utilizado em escavações a céu aberto, mas que pode ser utilizado também em escavações subterrâneas. Possui diâmetros variáveis de acordo com a carga de energia a ser transmitida na detonação. São os cordéis detonantes que acionam os diferentes tipos de espoletas.

\section{b. Sismografia}

A detonação dos explosivos gera a energia para a desagregação das rochas, como explicado no item a. "Plano de Fogo", no entanto, essa grande quantidade de energia não é totalmente aproveitada no processo de desagregação e se transforma em ondas mecânicas percorrendo o meio sólido e gerando vibrações e calor que podem ser sentidas nas vias adjacentes e terrenos vizinhos. Essa situação pode gerar desconforto e até possíveis danos (FRANCO, 2014). Por isso, é de suma importância o acompanhamento do comportamento dessas ondas mecânicas, principalmente em áreas urbanas e povoadas, pois as edificações próximas podem ser afetadas. Tal 
controle é realizado a partir do monitoramento das vibrações por sismógrafos, que geram relatórios, como o da Figura 13, onde é possível visualizar a disposição das informações no que diz respeito à localização de um furo em uma determinada seção, bem como sua projeção de avanço e as informações sismográficas referentes a ele. Estes relatórios permitem avaliar os efeitos da detonação do maciço e de acordo com Geraldi (2011), é comum se utilizar do conceito de velocidade de partícula, que é considerado como o melhor parâmetro caracteriza o comportamento da propagação de vibrações no interior das rochas, e deve ser medido em diversas direções. $O$ conceito de velocidade de partícula é caracterizado pela velocidade da vibração induzida a uma partícula do maciço rochoso pela detonação.

Para Mascarenhas (2014), cada estrutura apresenta uma frequência natural de vibração, e por esse motivo, pode-se estabelecer um limite de pico para a velocidade de vibração da partícula, medida em [mm/s], que seja aceitável e não apresente riscos as áreas residenciais.

Figura 13 - Relatório de sismografia gerado a partir do plano de fogo de uma seção definida.

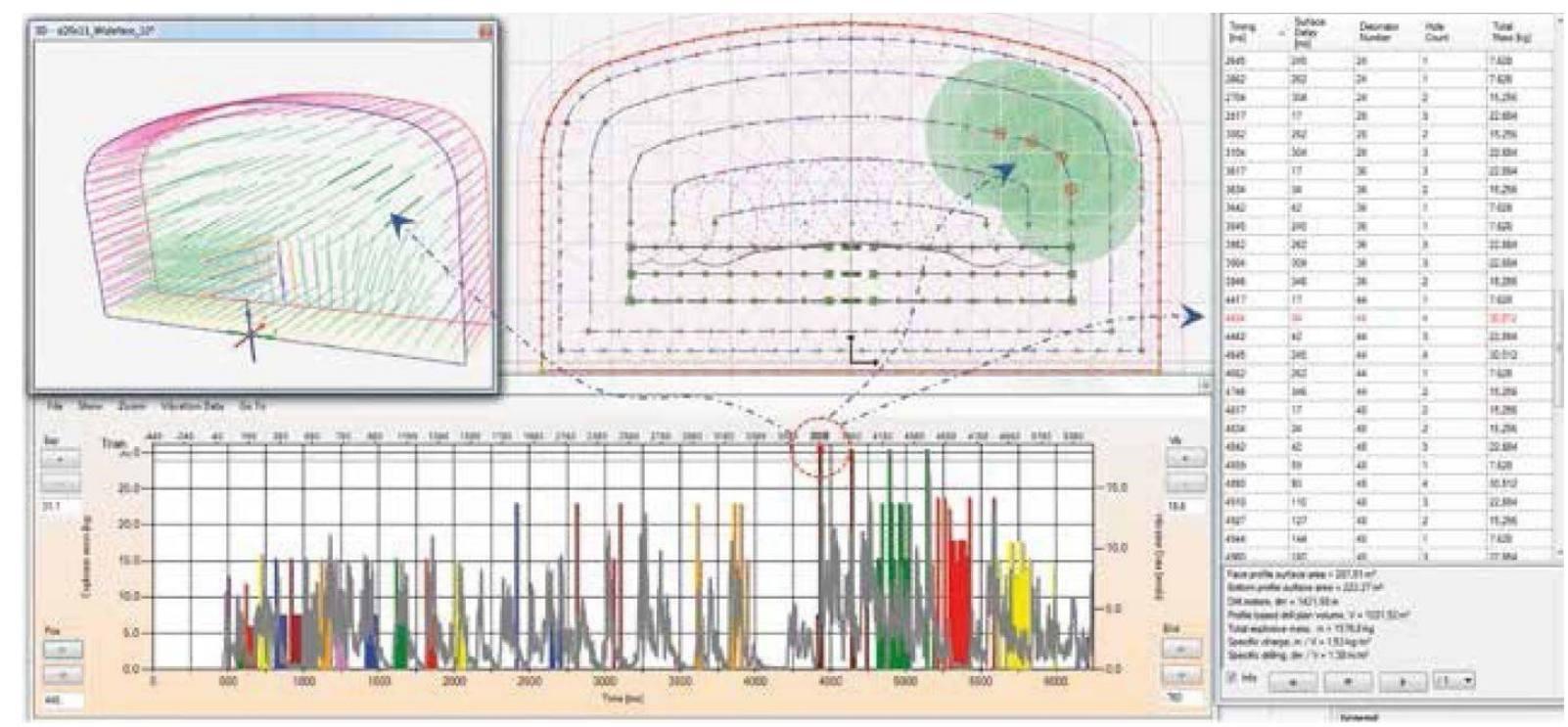

Fonte: Manual Sandvik. 


\section{c. Tratamento}

Os sistemas de suporte têm a função de conter os movimentos de deslocamento de blocos de rocha, de deformações do maciço, ou de rearranjar o confinamento dele, visando melhorar suas características de resistência e sustentação. Também são utilizados para introduzir um confinamento complementar, quando a capacidade de auto suporte do maciço não sustenta a solicitação de determinado empreendimento. Os sistemas de suporte e tratamento do maciço, considerando obras não confinadas ou obras subterrâneas se configuram com a utilização de tirantes, cambotas, concreto projetado e alguns outros elementos, que são representados no trabalho pelas enfilagens. Podem ser aplicados em conjunto ou separadamente e podem ser temporários ou definitivos, conforme a classificação de cada maciço, o tamanho da seção a ser escavada e a demanda de cada ação. Os tratamentos temporários são realizados a fim de garantir a continuidade e estabilização da obra, como por exemplo galerias de acesso. Já o tratamento definitivo é implementado para tornar o maciço estável durante sua vida útil.

Os sistemas de suporte e tratamento são amplamente utilizados em obras subterrâneas, onde normalmente são utilizados tirantes e enfilagens, recursos aderidos por penetração no maciço para estabilizar a concavidade da abóboda (em sua maioria) dos túneis, ampliando a resistência contra desabamentos. Concreto projetado e cambotas metálicas, também constituem elementos utilizados na superfície escavada, que restringem diretamente a movimentação do maciço, bem como sua deformação. Estes itens serão tratados abaixo.

\section{d. Tirantes}

Os tirantes têm função de contenção de blocos ou cunhas de rocha isolados por fraturas ou por combinações de fraturas com foliações. Usualmente são utilizados para evitar o desprendimento de blocos de rochas das paredes da escavação, e serão aplicados conforme a necessidade das condições geológicas locais, sendo utilizados também em obras de contenção de maneira geral, não sendo exclusivos à túneis. 
Pelo ponto de vista dos sistemas de suporte definitivos, os tirantes são aplicados ordenadamente distribuídos em uma malha geométrica, principalmente nos túneis, criando uma zona de rocha comprimida logo adiante da superfície de escavação. Esta região na qual a resistência foi modificada, atua como um arco de rocha, e restringe os deslocamentos e deformações do maciço localizado acima da seção de gabarito do túnel. A Figura 14 mostra os tirantes introduzidos para além das zonas de fraturas, de modo a prender o bloco de rocha.

Figura 14 - Tirante para reforço de rocha fraturada.

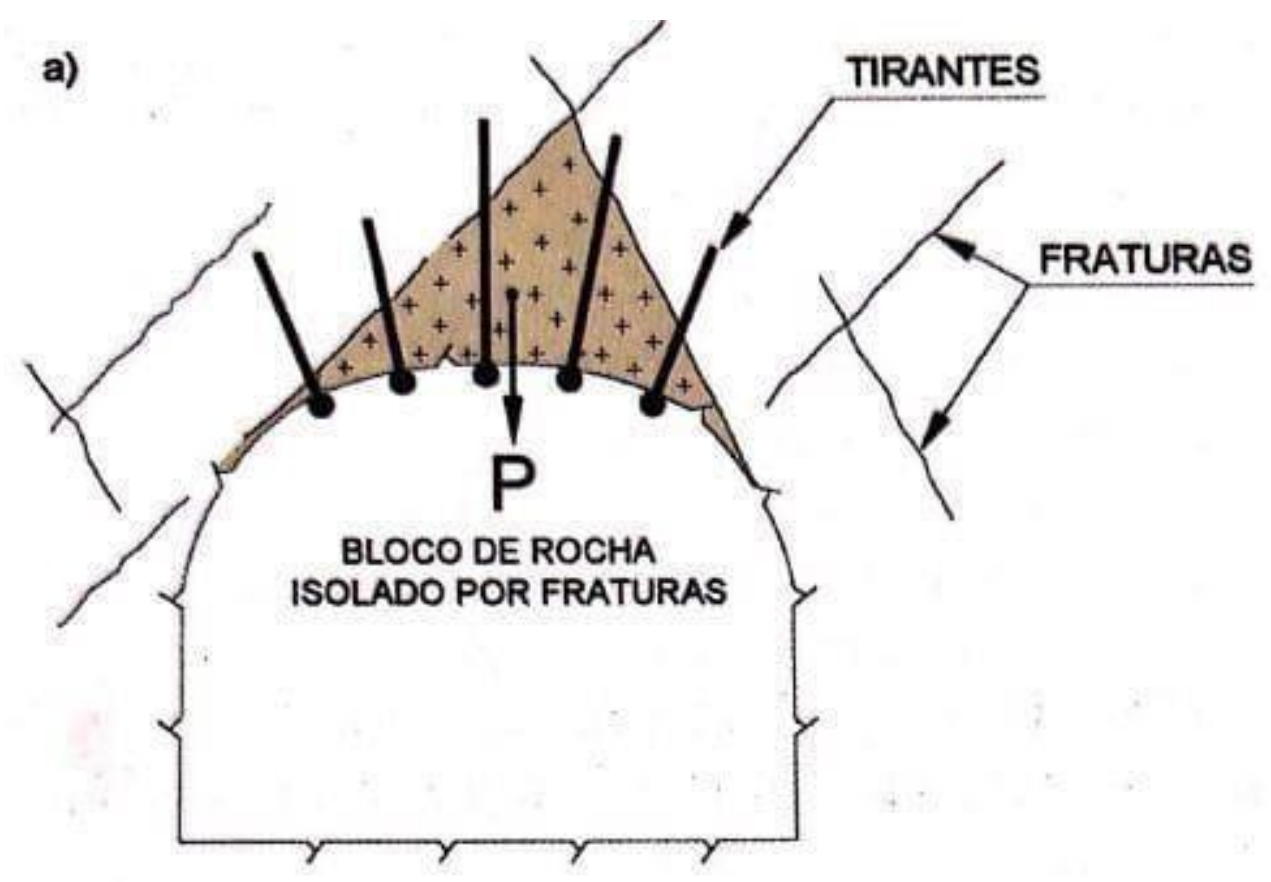

Fonte: adaptado de Hoek e Brown (1980).

Os tirantes são os mais utilizados para reforço da resistência de maciços rochosos, porque são versáteis, de rápida aplicação e de custo relativamente baixo se comparado a outros sistemas. Podem ser aplicados tanto para escavações a céu aberto quanto para escavações subterrâneas. Para maciços com muitos planos de ruptura e/ou zonas de falhas, o tirante tem sua fundação um pouco restringida, porque os deslocamentos de blocos menores de rocha continuam imprevisíveis, além da dificuldade de determinação da capacidade de carga de cada elemento de ancoragem, primordialmente em maciços heterogêneos. 


\section{e. Cambotas}

Outro sistema de suporte em túneis, é o de cambotas metálicas, que funciona muito bem quando o tempo de autossustentação do maciço é muito reduzido. As cambotas se constituem em segmentos metálicos que são aparafusados ou soldados alinhados às paredes de escavação um seguido do outro, e assim sucessivamente. Elas acompanham o gabarito da abóboda do túnel, comumente ficando em formato de arco, e as paredes, se apoiam no piso do túnel. Os empuxos oriundos das deformações do maciço são todos escorados nas cambotas, que por sua vez, transferem estas cargas para o piso do túnel. É comum se utilizar este sistema em trechos com muitas zonas de falhas ou planos de ruptura, tal como em trechos de rocha muito alterada. Quando as rochas do maciço são de uma classe com pouca ou nenhuma alteração, as cambotas são simplesmente apoiadas diretamente no piso. Para maciços predominantemente em solo, os pés das cambotas são apoiados em sapatas de concreto no bordo da pista para acomodar a distribuição dos esforços à capacidade de carga do solo. Para solos pouco resistentes, ou quando ocorrem esforços laterais, os dois pés das cambotas são travados por concreto projetado ou concreto armado aplicado sobre o piso formando um arco invertido, como se pode observar na Figura 15. 
Figura 15 - Cambota metálica treliçada aderida ao suporte.

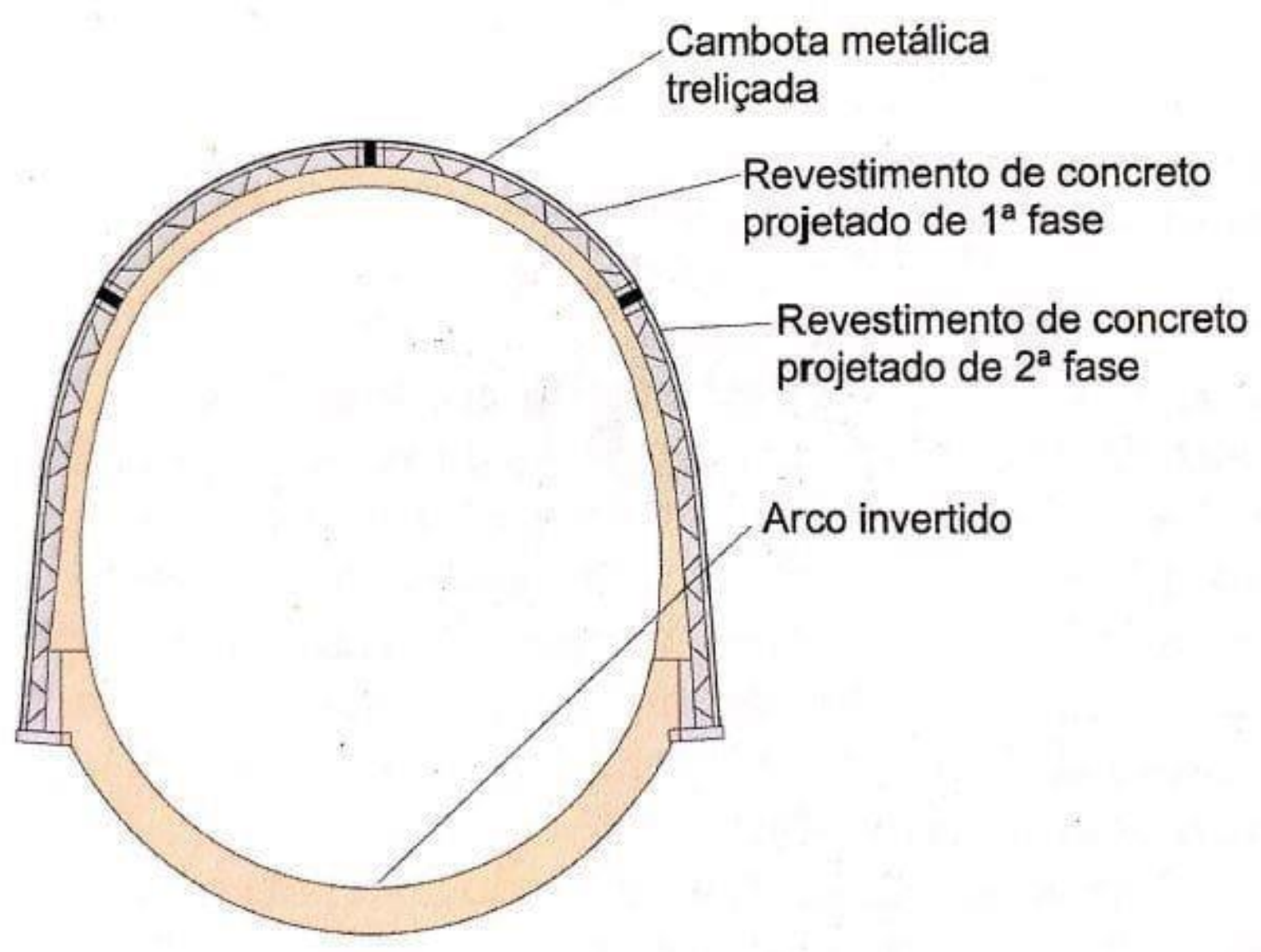

Fonte: Monticeli e Oliveira (2018).

\section{f. Concreto Projetado}

O concreto projetado pode ser definido como uma mistura pastosa, mas consistente, de água, cimento e areia, com a possibilidade de adicionar aditivos. Essa mistura é projetada por um jato de alta velocidade utilizando bombas especiais, formando uma camada de sustentação sobre a superfície a ser tratada. As primeiras experiências com concreto projetado ocorreram nos Estados Unidos da América em 1910. O processo do concreto projetado se tornou o principal procedimento do sistema NATM, que o popularizou seu uso em túneis e taludes.

A compacidade do concreto projetado pode e deve ser garantida através de uma aplicação com a maior pressão possível. Entretanto, em maciços de baixa resistência 
a pressão deverá ser reduzida para evitar desplacamento. Diversos aditivos podem ser utilizados, geralmente para acelerar a pega da argamassa ou para aumentar a fluidez da mistura, melhorando em seu bombeamento. Para melhorar a resistência à tração do concreto projetado, as fibras de aço têm conquistado cada vez mais espaço, funcionando com a armadura da mistura, e atuando principalmente na melhora da ductilidade. Mais recentemente, foi adotada a incorporação da areia quartzosa de granulometria muito fina, utilizada para melhorar a aderência do concreto projetado (AMARAL FILHO, 1995).

Na Figura 16 é possível observar um desenho esquemático onde o concreto é projetado manualmente por uma pessoa, mas atualmente é usual a projeção realizada por máquinas previamente programadas.

Figura 16 - Aplicação de concreto projetado.

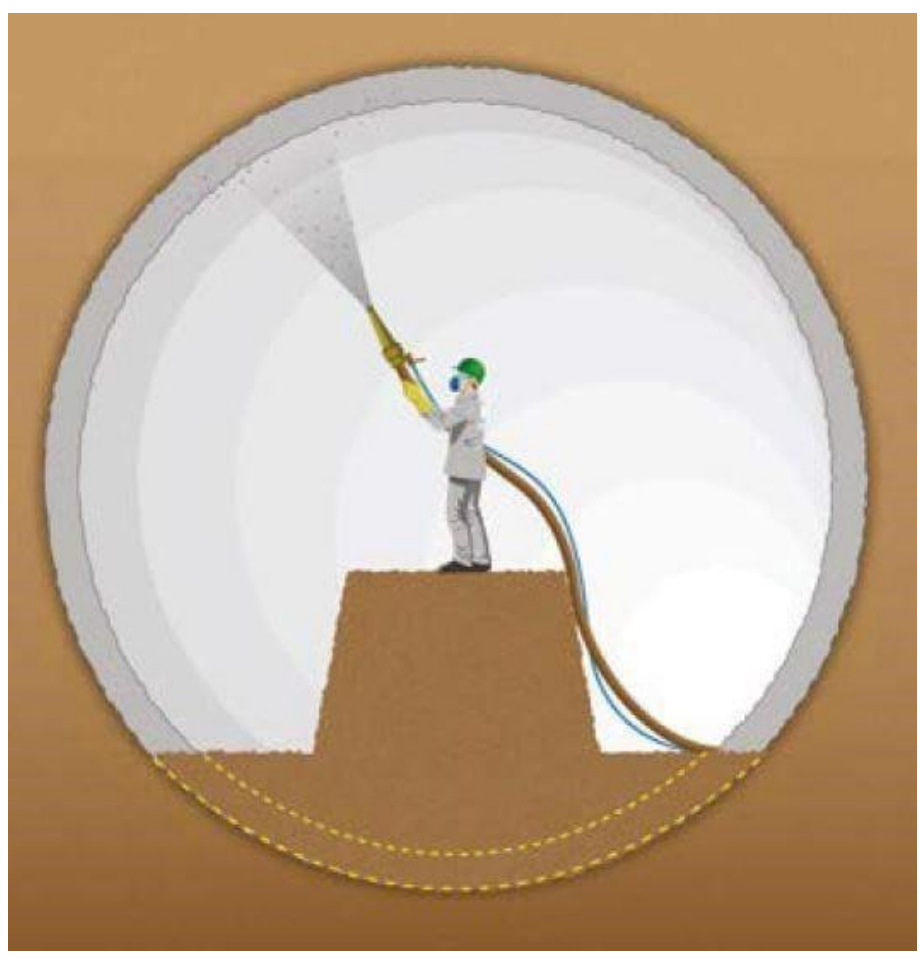

Fonte: Solotrat - Engenharia Geotécnica LTDA, 2018.

Para a função de suporte temporário, deve-se aplicar o concreto projetado logo após a escavação do maciço, tanto em túneis em solo como em rocha. Uma vez escavados, 
os maciços naturais permanecem sem sofrer deformações apreciáveis por um tempo variável, que depende das características de cada maciço. Este período é conhecido como o tempo de autossuporte.

\section{g. Enfilagens}

As enfilagens viabilizam a escavação porque reforçam os maciços de solo ou rocha na abóboda dos túneis. Sua instalação é dada a partir da frente de escavação com projeção para o trecho subsequente a ser desagregado a partir das detonações, e geralmente são aplicadas em solos com baixa resistência ou em rochas muito alteradas, garantindo um suporte extra (RIBEIRO NETO, 1999). Podem ser feitas por perfis de aço, cravados acima da abóboda do maciço, ou também podem ser constituídas de tubos vasados de aço, que são introduzidos acima da abóboda do maciço através de perfurações (tal como as perfurações para introdução dos explosivos) e submetidas à injeção de calda de cimento, que se espalha a partir de válvulas manchete, como ilustrado na Figura 17.

Figura 17 - Enfilagens com válvula manchete para injeção de calda de cimento.

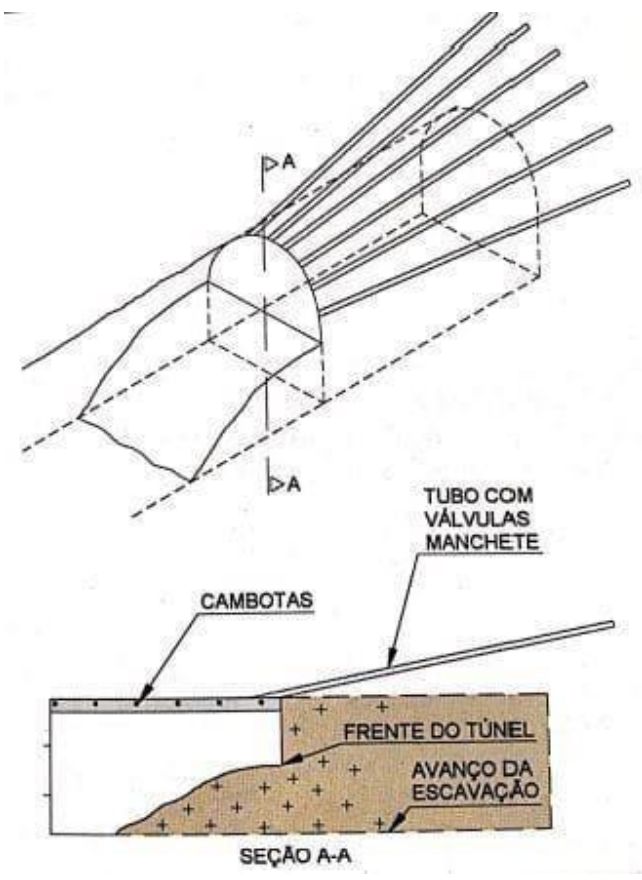

Fonte: Guimarães Filho e Guimarães Neto (1995). 


\section{ANÁLISE DE UMA APLICAÇÃO DO NATM NO BRASIL}

O caso prático refere-se a um trecho de ampliação da Rodovia dos Tamoios - SP099 próximo a cidade de Caraguatatuba/SP, conforme Figura 18. É um empreendimento arrojado, pois lida com desafios ambientais, geológicos e de engenharia, que o torna bastante complexo.

O projeto ambiental foi muito detalhado poque aproximadamente $85 \%$ da obra está inserida no Parque Estadual da Serra do Mar, que é a maior unidade de conservação de toda a Mata Atlântica. O trecho ascendente é constituído por túneis e viadutos para gerar o menor impacto ambiental possível, evitando supressão vegetal pelos taludes de cortes e aterros.

Figura 18 - Região duplicada da Rodovia dos Tamoios - SP099.

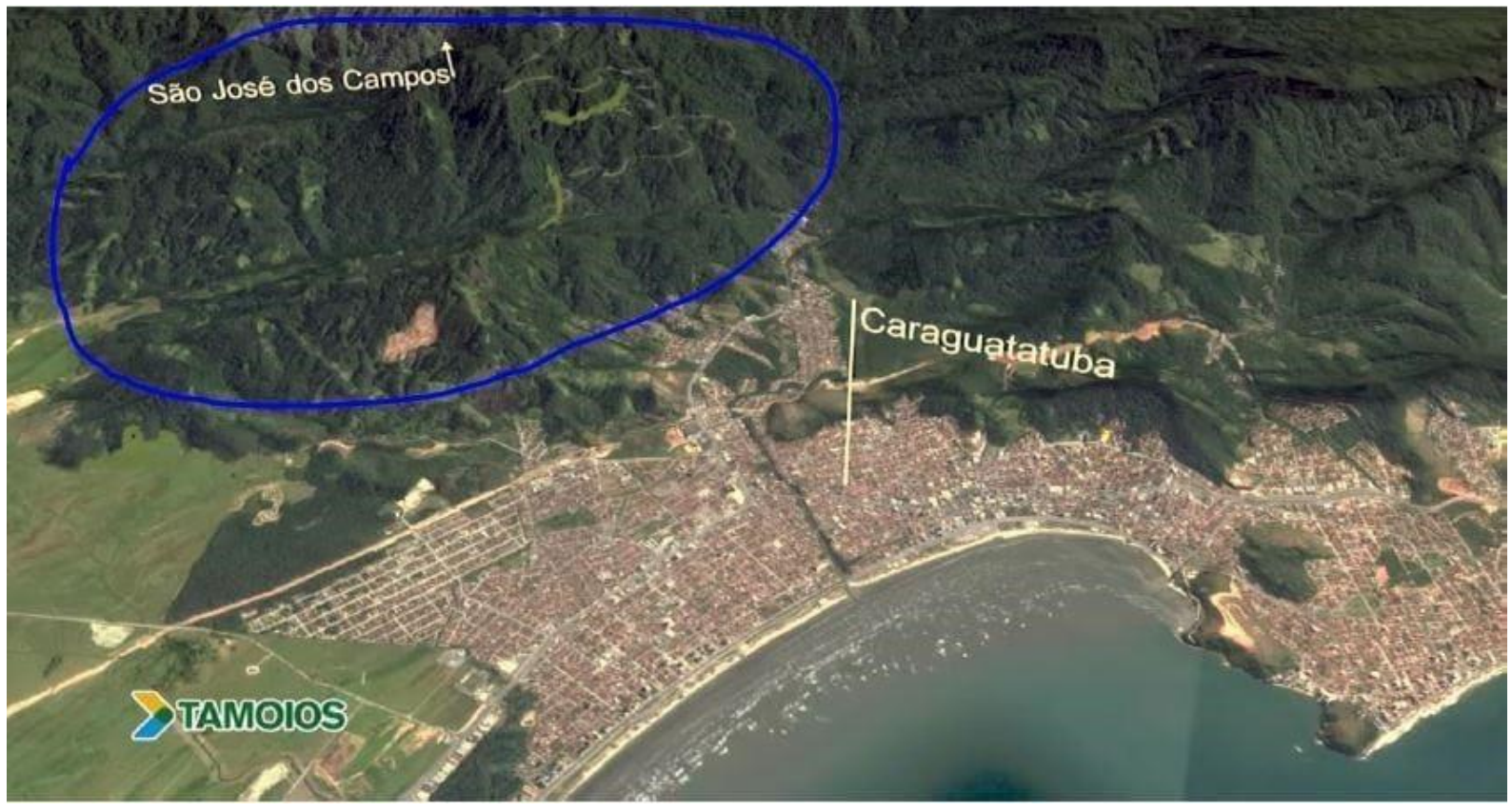

Fonte: Concessionária Tamoios (2019).

Os 4 túneis rodoviários que totalizam 12,8 quilômetros de extensão, contém o maior túnel rodoviário do país, com 5.556 metros, cujo traçado se observa na Figura 19, e ainda pontes e viadutos que somam 2,6 quilômetros de extensão. Em toda a obra, serão utilizados 285.000 metros cúbicos de concreto e 7.000 toneladas de aço CA-50. 
A previsão é movimentar cerca de 1,9 milhões de metros cúbicos de material proveniente das escavações dos túneis, que a partir de análise em laboratório, serão reaproveitados, na medida do possível, na produção de agregados para concreto, aterros e pavimentação.

Figura 19 - Traçado do novo trecho em vermelho e traçado antigo em amarelo.

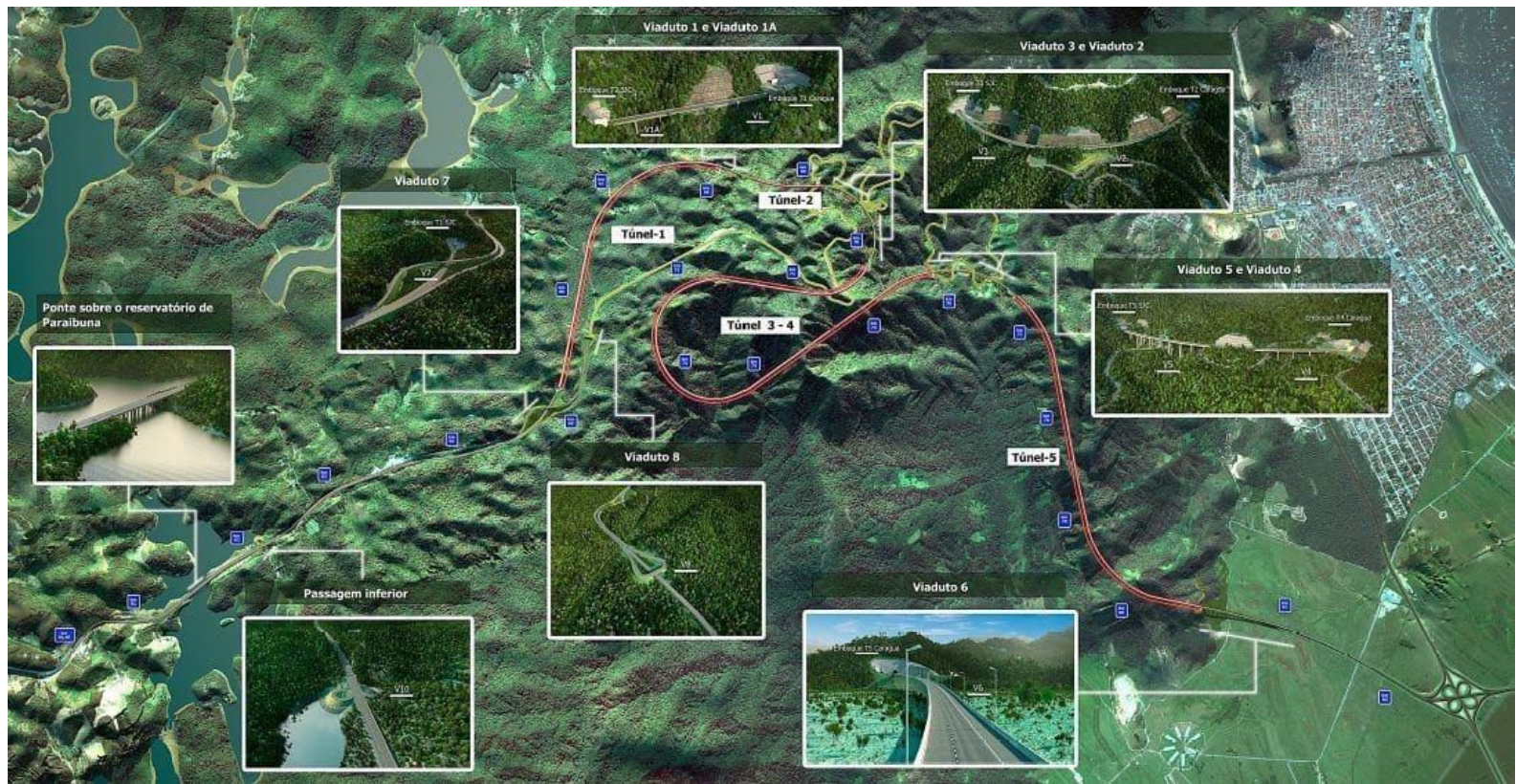

Fonte: Construtora Queiroz Galvão (2019).

\subsection{DEFINIÇÃO DO TRAÇADO}

O primeiro passo no empreendimento foi realizar o levantamento topográfico da região para definir qual seria o melhor traçado geométrico do trecho. O local é formado por diversos vales e montanhas de difícil acesso, então o levantamento topográfico foi realizado através de informação de satélites e drones para a obtenção de informação geográficas mais precisas.

\subsection{INVESTIGAÇÃO GEOLÓGICA}

Após a definição do traçado, foi necessário realizar estudo sobre os maciços a serem escavados. Esta etapa foi realizada através de sondagens a percussão conforme especificações da NBR 6484 da ABNT, e em caso de impenetrabilidade, o furo 
continua através do método rotativo até a profundidade preestabelecida. Para a elaboração dos perfis geológicos, foram realizadas sondagens mistas com sondagens rotativas para regiões em rocha e sondagens à percussão SPT (Standard Penetration Test) para regiões em solo. Esta etapa representa um alto custo na fase do projeto e por isso todas as sondagens receberam uma padronização no limite da profundidade de até 70 metros, viabilizando economicamente a caracterização. Em alguns trechos, o recobrimento do maciço até o início da abóboda do túnel chegou a 400 metros, distância que torna impraticável o serviço de acordo com as premissas estabelecidas. Desta forma, estimou-se a classe de rocha de acordo com as sondagens realizadas, auxiliando na elaboração do perfil longitudinal detalhado de cada um. Conforme o túnel era escavado e as frentes de serviço avançavam, realizava-se o chamado furo tático para definir de forma mais detalhada o perfil das rochas que seria encontrado mais à frente, uma vez que as sondagens não forneciam segurança suficiente sobre a caracterização de cada maciço. Este furo se assemelha à uma sondagem, e garante o tipo de rocha encontrada, possibilitando alocar de forma exata todos os equipamentos para a escavação da seção em específico. Os furos táticos foram feitos analisando os 20 metros sucessores das frentes de serviço, o que garantiu uma ótima margem de segurança, considerando que o avanço pelo NATM é baixo devido a heterogeneidade dos maciços naturais. Os furos táticos também têm muita importância na definição das regiões que possuem planos de falhas e rupturas das rochas, propiciando uma tomada de ação preliminar no que tange o tratamento do maciço, evitando possíveis desabamentos, overbreaks e underbreaks exagerados. 0 Túnel 1, por exemplo, necessitou de constantes atualizações na compartimentação geológica a partir dos furos táticos, pois se encontrava em uma região com rochas de baixa resistência e difícil acesso das sondagens.

\subsection{PLANO DE FOGO}

Os planos de fogo utilizados na escavação dos túneis da Rodovia dos Tamoios seguiram especificações e distribuições de furos de acordo com o tipo de seção adotado, e levando em consideração também o perfil geológico previamente caracterizado, exemplo mostrado na Figura 20. 
Figura 20 - Plano de fogo conforme as condições geológicas e informações topográficas.

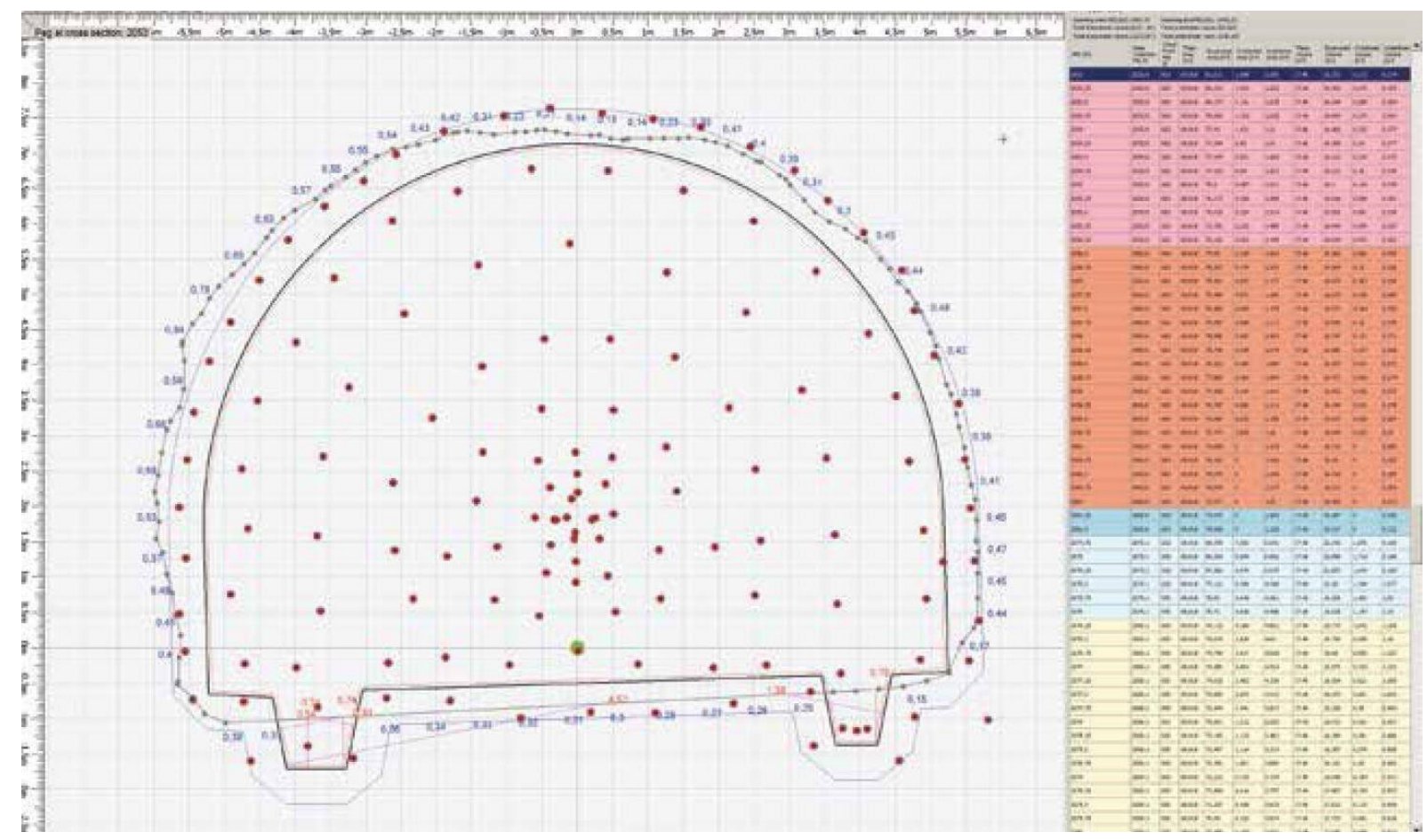

Fonte: Manual Sandvik.

O equipamento utilizado para realizar os furos, é uma rotoperfuratriz eletro-hidráulica, popularmente chamada de "Jumbo". Ela possui duas ou três lanças de perfuração que seguem um plano de fogo pré-estabelecido. A lança de perfuração alcança até 5,8 metros e pode ter espessura variável de acordo com o bit colocado em sua extremidade, que é uma peça de metal que possui protuberâncias responsáveis pelo desmonte da rocha e orifícios responsáveis pela passagem de água em alta pressão, que também auxilia nessa perfuração. Detalhes podem ser observados adiante na Figura 21. 
Figura 21 - Bit acoplado à lança do Jumbo, utilizado na perfuração da rocha.

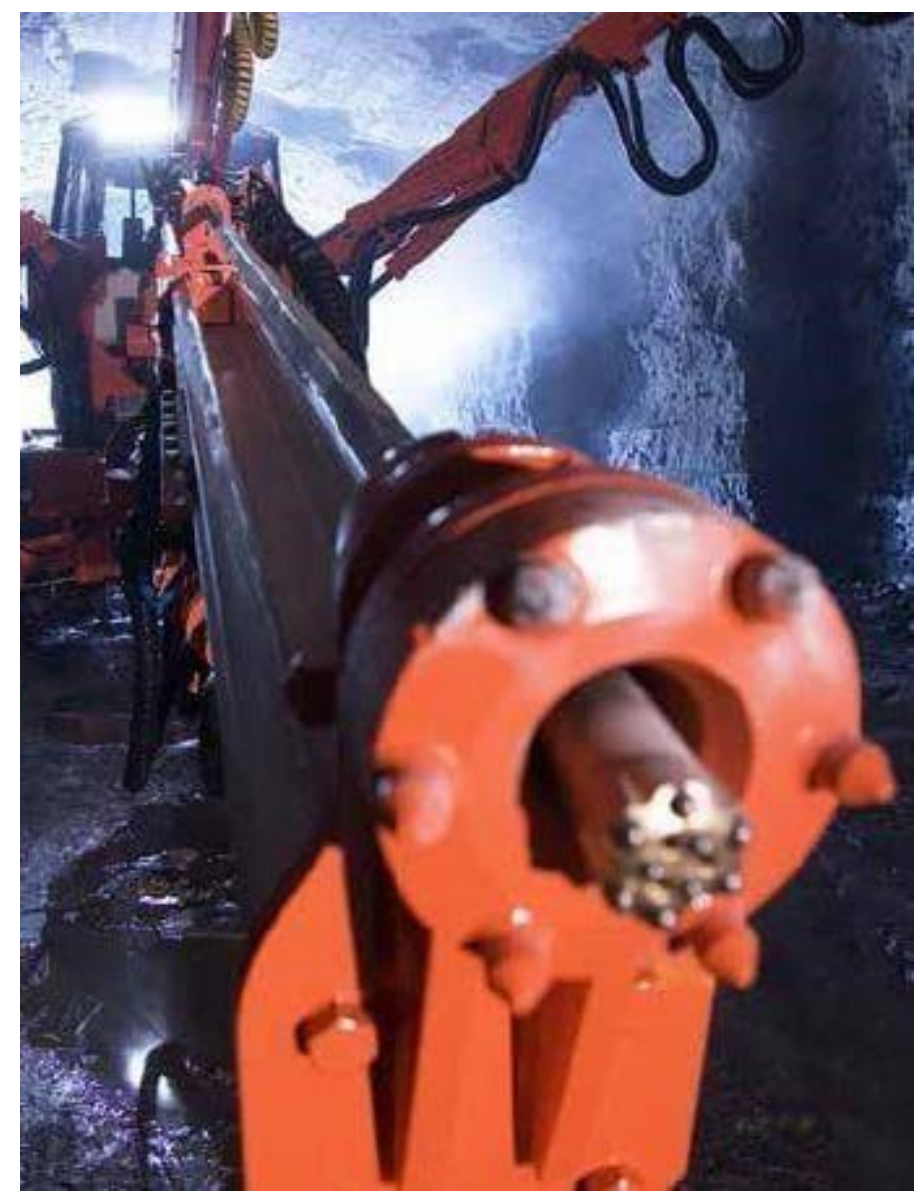

Fonte: Manual Sandvik.

A peça foi constantemente afiada, porque na perfuração de rochas praticamente sãs ocorre grande desgaste. $O$ desgaste provocava o descarte frequente para manter bom desempenho das lanças do Jumbo. A manutenção desta peça deve ser bem planejada, porque possui alto custo e pode impactar no custo total do empreendimento.

Os planos de fogo foram projetados através de um software da fornecedora do Jumbo chamado T-CAD, ilustrado na Figura 22. As informações topográficas da seção transversal e geológicas do maciço são inseridas no software produzindo um perfil de plano de fogo personalizado para cada seção. Tanto o T-CAD como o Jumbo possuem interface direta com o Estação Total, que é o equipamento topográfico que fornece as coordenadas dentro do túnel, como na Figura 23. Isso possibilita que os furos sejam 
realizados exatamente na posição programada pelo sistema. Através do software o furo era dimensionado com a profundidade, diâmetro e quantidade de explosivos.

Figura 22 - Software T-CAD com o plano de fogo desenvolvido para uma determinada seção.

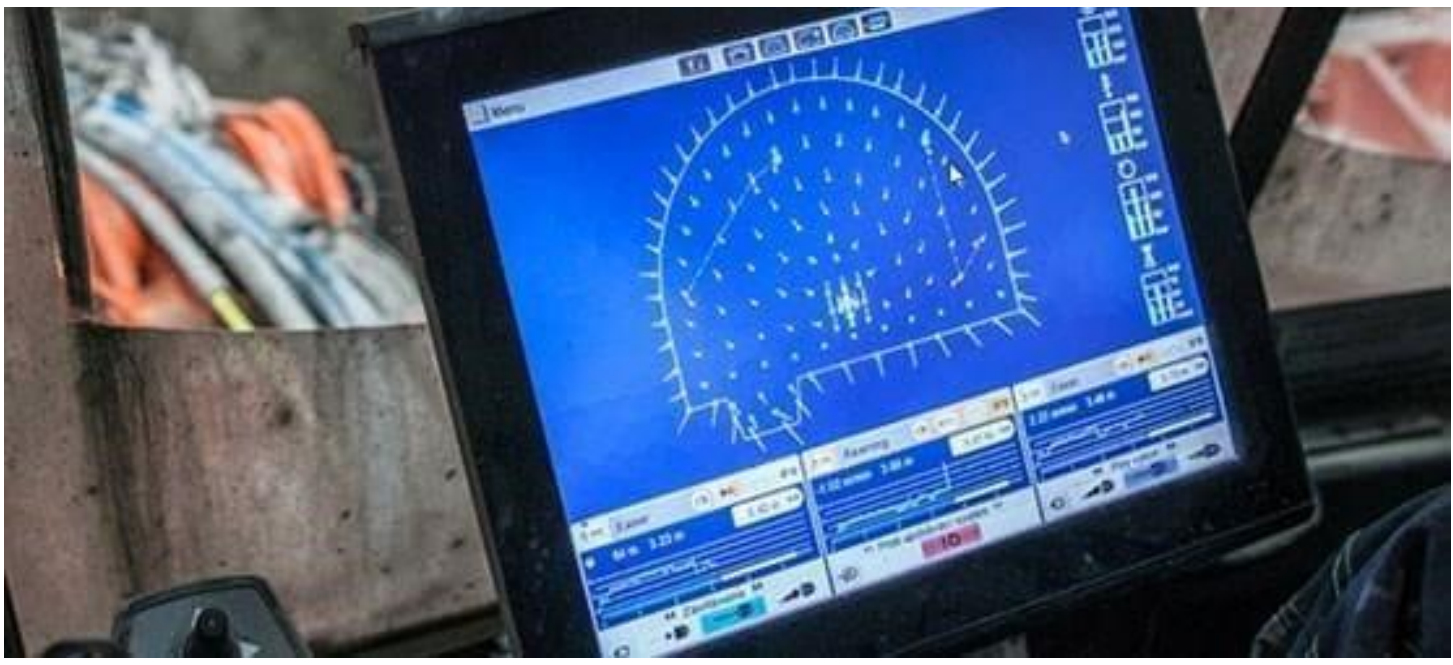

Fonte: Manual Sandvik.

Os furos foram marcados com uma tinta branca para uma melhor visualização do operador do Jumbo, porque mesmo o funcionamento sendo automatizado, também possibilita interferência manual do operador. Ao final da perfuração do plano de fogo, o Jumbo gera um relatório com as informações precisas de cada furo, indicando se houve algum erro em relação a profundidade, ângulo de entrada e diâmetro do furo. 
Figura 23 - Varredura do Jumbo para obter a posição topográficas dentro do túnel.

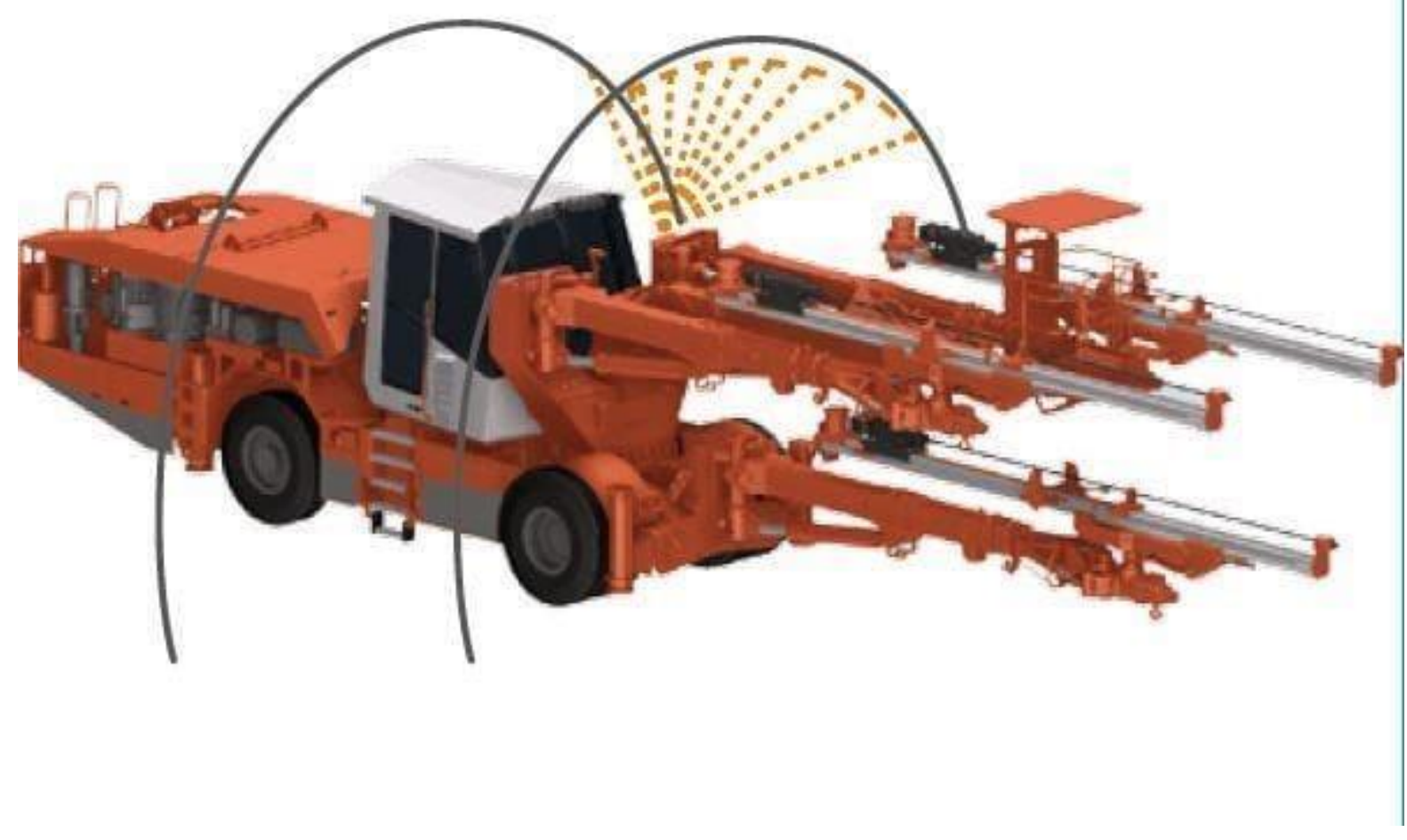

Fonte: Manual Sandvik.

As detonações foram acompanhadas por um profissional especializado, conhecido como Blaster, que foi responsável pelo planejamento e análise de riscos do uso de explosivos. A participação deste profissional tem caráter obrigatório em qualquer atividade que lide com desmonte de rochas a partir de detonações à fogo, tal como em pedreiras ou escavações de minas.

Uma boa detonação ocorrerá existindo uma face livre capaz de potencializar a fratura da rocha, gerando trincas radiais e fissuras que darão sequência ao desmonte da rocha. Portanto, as detonações não podem ocorrer ao mesmo tempo, sendo necessário gerar faces livres subsequentes para os furos subsequentes.

A detonação dos túneis da Rodovia dos Tamoios ocorreu a partir do acionamentos consecutivos de espoletas em um intervalo de 25 milissegundos e possuíam a 
sequência a seguir: ao carregar totalmente a seção a ser detonada, a frente de serviço era desmobilizada e o túnel precisava ser completamente evacuado para não gerar riscos à vida humana; Do lado de fora do túnel, era acionada uma caneta iniciadora, que emitia energia através do fio de propagação chamado leadline; Esse fio oco transmitia energia a partir de um gás interno até o cordel NP $40 \mathrm{com}$ velocidade de propagação de $7500 \mathrm{~m} / \mathrm{s}$; O cordel por sua vez acionava as espoletas, que eram responsáveis por garantir diversos tempos de detonação, evitando que a explosão ocorresse de uma só vez. Especificamente nos túneis em estudo, foi utilizado ainda um booster, com a função de potencializar o impacto garantindo assim, o acionamento da emulsão. A quantidade de emulsão introduzida em cada furo foi dimensionada a partir da classificação das rochas e do quanto de avanço era previsto para cada ciclo de escavação. Um exemplo de montagem na face da seção a ser escavada pode ser observada na Figura 24.

A ordem de detonação seguiu a concentração de carga que se dá no centro da seção onde fica localizado o pilão, cuja tendência de deslocamento das demais explosões era para esse mesmo centro, garantindo uma detonação mais eficaz a partir da desagregação completa das rochas, com as demais explosões ocorrendo no contorno do túnel e na sapateira. 
Figura 24 - Explosivos e equipamentos auxiliares instalados no pilão (centro) para a detonação.

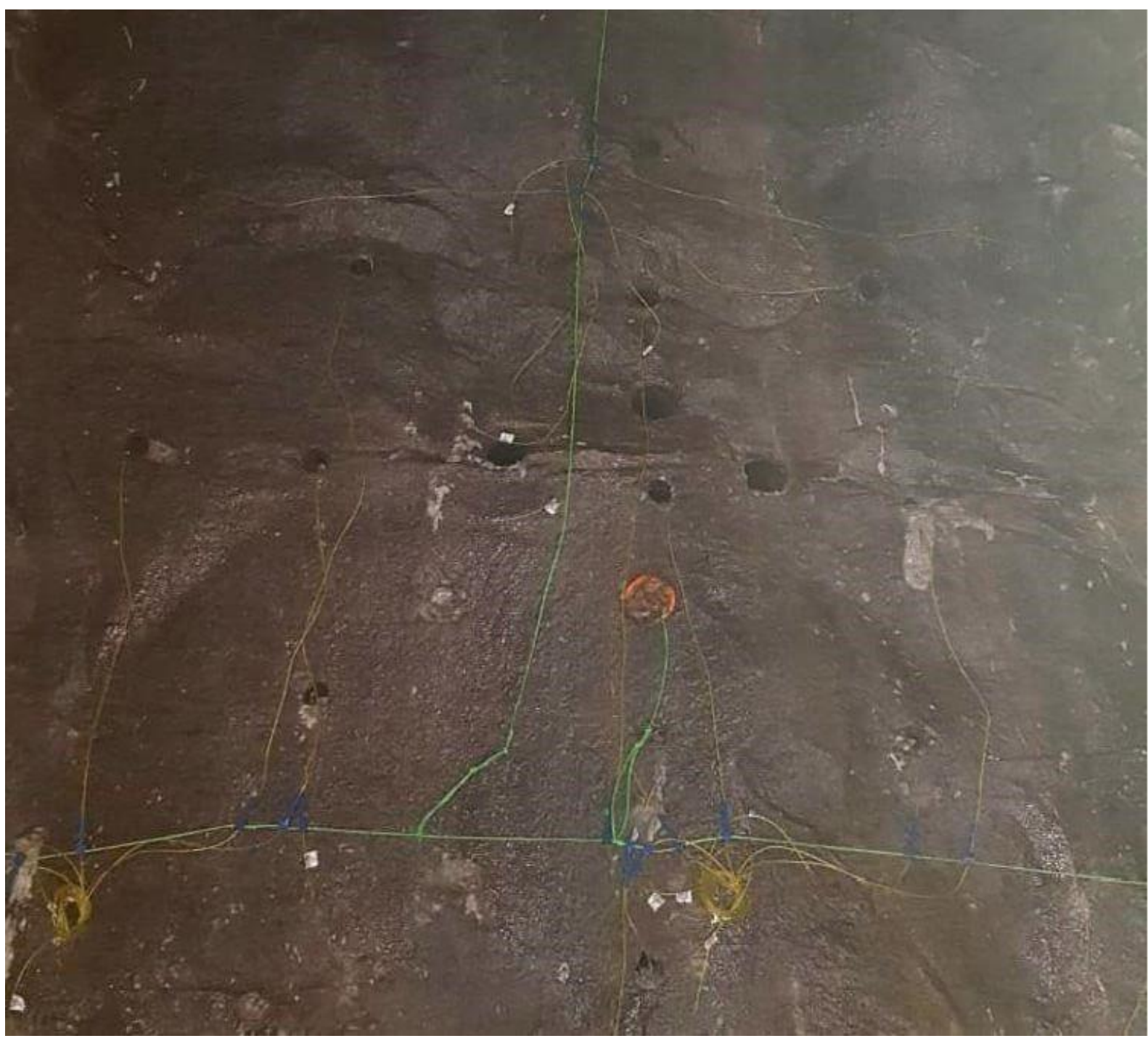

Fonte: Construtora Queiroz Galvão.

\subsection{LIMPEZA}

Após a detonação, com um potente sistema de ventilação (Figura 25) os gases tóxicos eram expulsos. Para verificação da eficiência do processo um profissional responsável pela segurança do trabalho utilizava um equipamento específico para medição dos gases e liberar a frente de serviço. 
Com a frente liberada, o processo de limpeza mecânica, chamado choco mecânico, era feito com o auxílio de escavadeiras com rompedor hidráulico e de pás carregadeiras, que carregavam para fora do túnel os blocos de rochas desagregados. Após essa limpeza mecânica ocorria o choco manual realizado por colaboradores e martelos pneumáticos, que retiravam os blocos menores de rochas que corriam o risco de se desprender do maciço, deixando a seção completamente livre e segura para o próximo carregamento. Nesta fase de choco manual com o auxílio de uma plataforma elevatória, eram retirados também os underbreaks, que são rochas sobressalentes ao gabarito da seção que não foram desagregadas por insuficiência da detonação. Exemplos na Figura 26. Os underbreaks são comumente evitados a partir de um dimensionamento preciso dos explosivos, porque geram atraso no ciclo de escavação, porque é um desmonte mecânico de rocha mais lento.

Figura 25 - Sistema de ventilação.

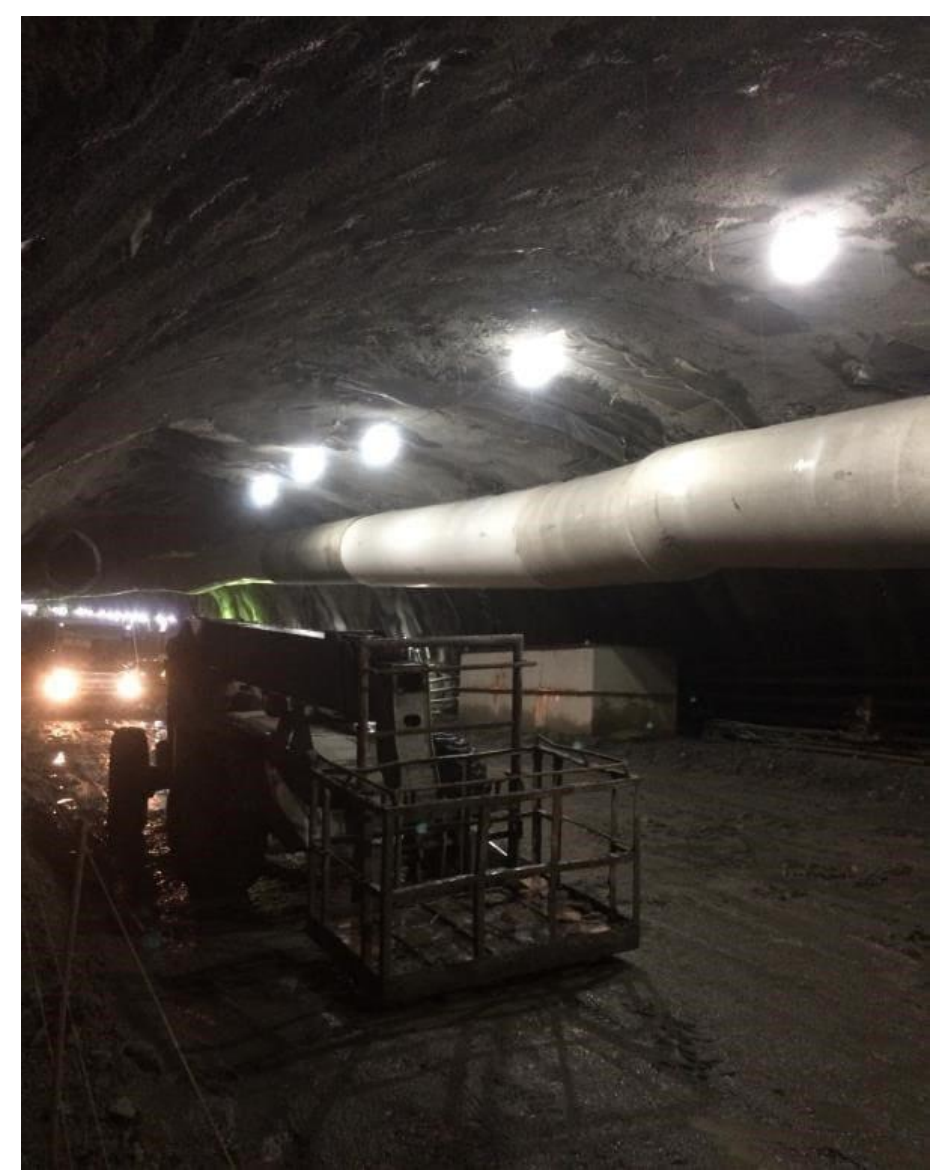

Fonte: O Autor (2019). 
Figura 26 - Bate choco manual retirando pequenos volumes de rochas fraturadas.

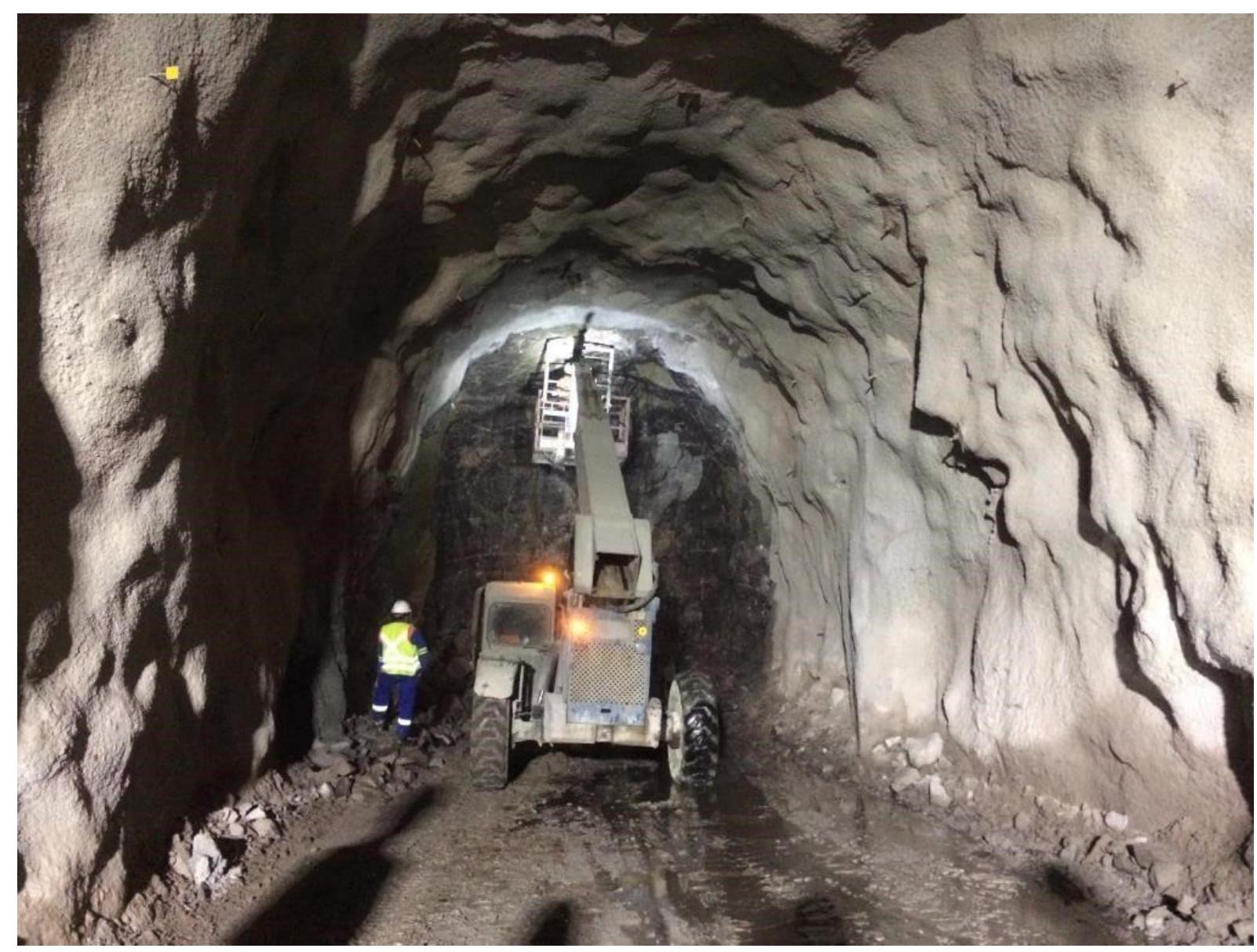

Fonte: Construtora Queiroz Galvão (2019).

\subsection{DRENAGEM}

A drenagem dos túneis é de suma importância para o processo de escavação, pois está diretamente ligada à estabilidade do maciço. O maciço possui um grande volume de água confinado, que com as consecutivas detonações começam a percolar para o gabarito da seção do túnel escavado, gerando por vezes, verdadeiros escoamentos com uma alta concentração de água. Esta concentração em alguns pontos, gera instabilidades na estrutura, com pontos de tensão elevados. A fim de evitar possíveis desmoronamentos foram utilizadas micro calhas, como na Figura 27, chamadas de drainpacks, que direcionam o caminho a ser percorrido pela água até as valetas (Figura 28) nos bordos da pista e posteriormente bombeada para fora do túnel. $\mathrm{O}$ drainpack era pregado no maciço identificando pontos críticos de concentração de 
água, e aderido ao mesmo através de argamassa via seca. Após o período de construção dos túneis, os drainpacks também serão úteis na fase de operação.

Figura 27 - Drainpacks instalados gerando um caminho para água.

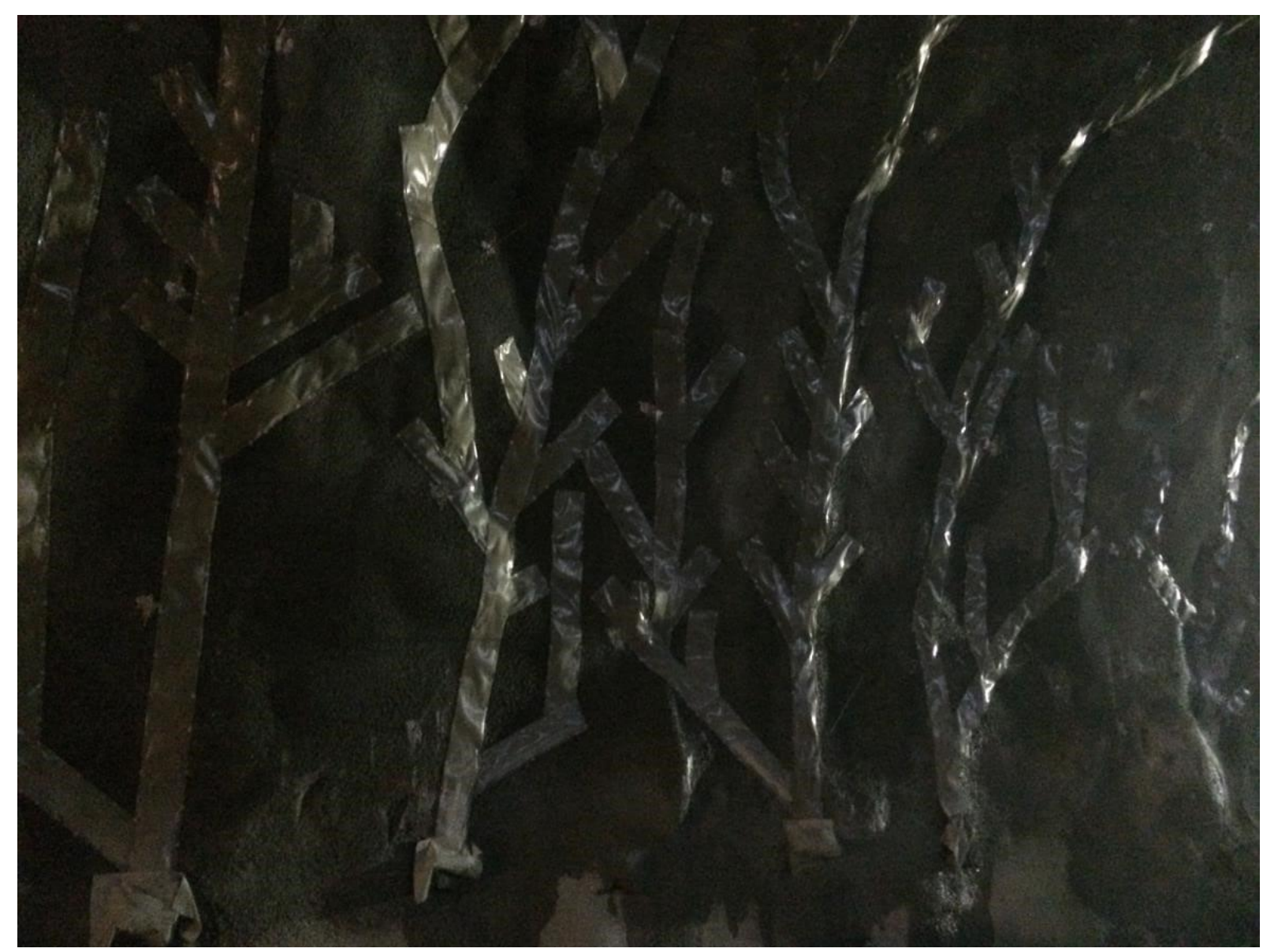

Fonte: O Autor (2019). 
Figura 28 - Valetas que escoarão a água durante a construção e operação do túnel.

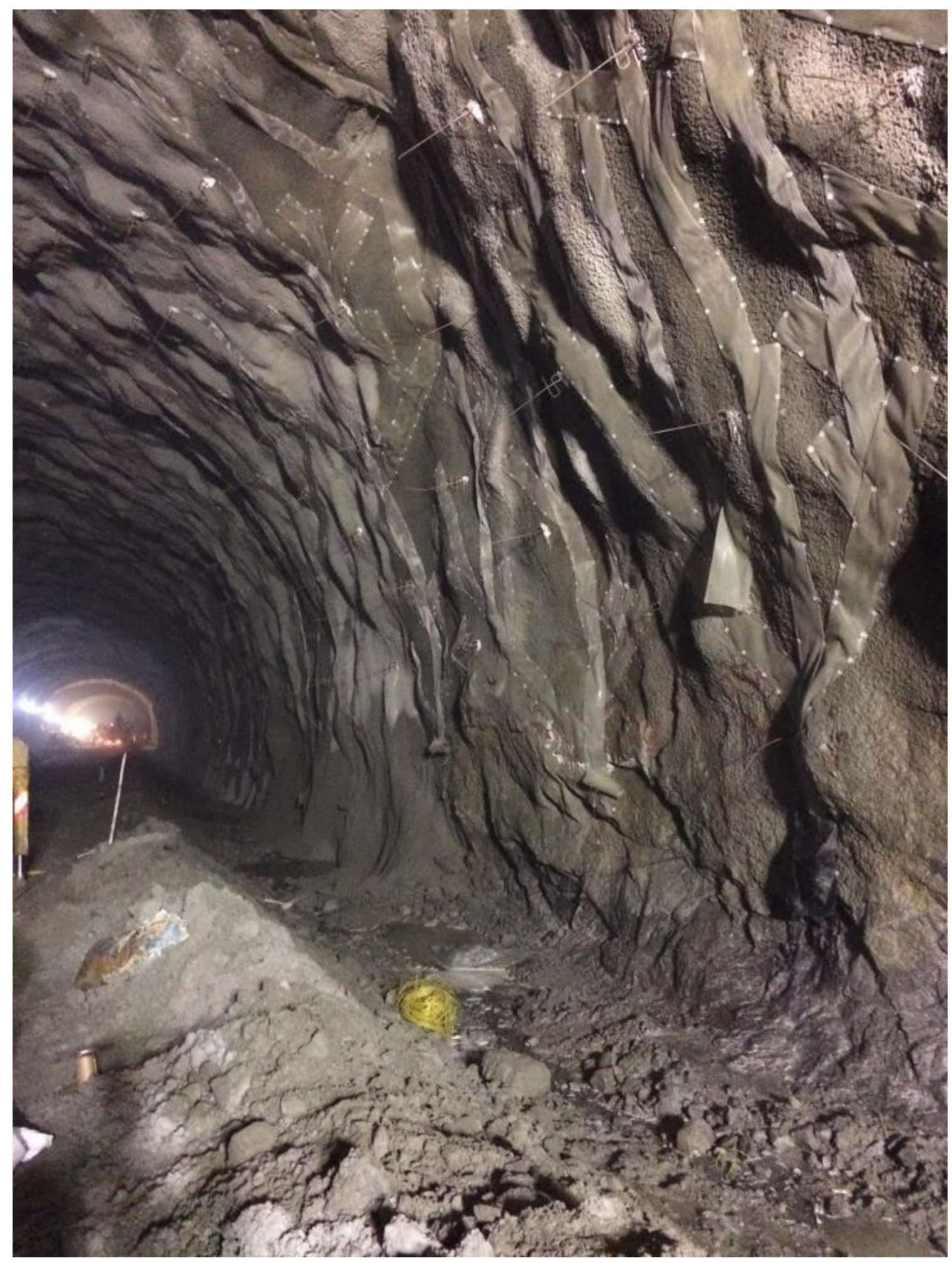

Fonte: O Autor (2019).

Disponível em: https://www.nucleodoconhecimento.com.br/engenharia-civil/escavacao-de-tuneis 


\subsection{CONCRETO PROJETADO}

O concreto projetado é uma das primeiras etapas no tratamento dos maciços após a detonação. Nos túneis avaliados o concreto possuía um FCK (resistência característica à compressão) de 25MPa divididos em duas camadas.

$\mathrm{O}$ revestimento primário utilizou cimento $\mathrm{CP} V$ de pega rápida e aditivos superpastificantes e de pega. Fibras metálicas foram utilizadas para diminuir a possibilidade de fissuração por retração, fazendo o papel da armadura do concreto. Apesar do alto custo, fibras metálicas foram utilizadas em alternativa as telas metálicas para armadura do concreto porque tornaria a aplicação muito lenta em razão de serem moldadas manualmente à forma do maciço, além de tornar o processo exposto à erros humanos. As fibras metálicas foram adicionadas ao concreto na usina, sem riscos de alteração do traço e a projeção foi feita pelo equipamento da Figura 29, aumentando a produtividade na fase de tratamento primário dos túneis. A redução de tempo e erros compensa o custo com a utilização de fibras metálicas. O mangote do robô de projeção possuía abertura suficiente para permitir a passagem das fibras metálicas e feito por via úmida, evitando possíveis erros humanos. A pressão foi controlada a fim de evitar o efeito de reflexão do concreto projetado, que é o efeito de se desprender do maciço devido à alta pressão de impacto.

Figura 29 - Robô para projeção do concreto.

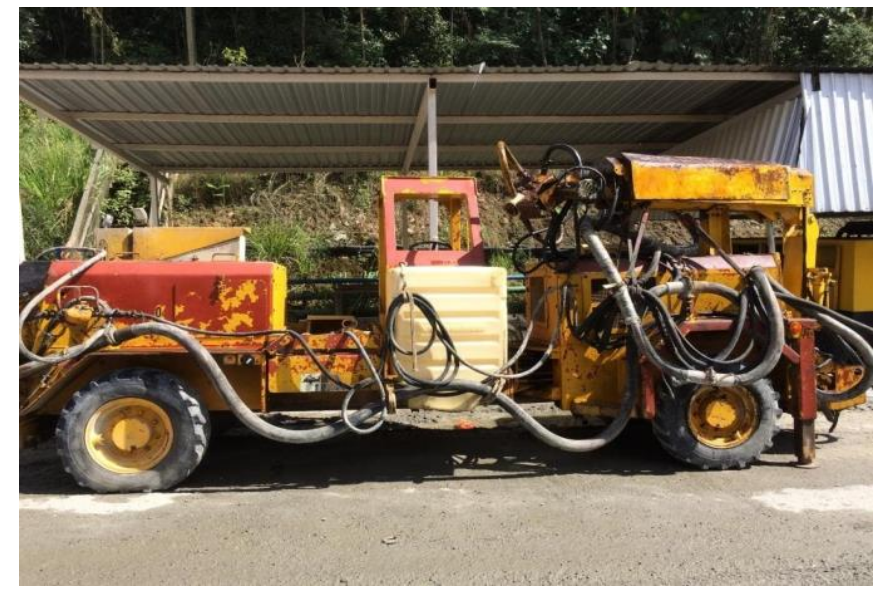

Fonte: O Autor (2019). 
O revestimento secundário teve a espessura definida de acordo com a classificação do maciço rochoso, então as camadas mais espessas do concreto projetado foram utilizadas em maciços com uma classe de rocha de qualidade baixa. Analogamente, maciços rochosos de melhor qualidade recebiam uma camada menos espessa. Nesta segunda camada foram utilizadas fibras de polipropileno. A motivação foi a possibilidade de um eventual incêndio dentro do túnel. O concreto quando exposto a altas temperaturas provoca o efeito spalling, que é uma expulsão repentina e brusca, que lança grandes pedaços de concreto, colocando em risco pessoas e bens materiais próximos. A microfibra de polipropileno é incorporada ao concreto e com o aumento brusco de temperatura carbonizam, formando capilares de drenagem, direcionando o vapor de água formado pelo calor. Caso o concreto não resista ao incêndio, não irá se quebrar de forma explosiva, apenas irá desagregar em pequenas lascas, oferecendo menos risco aos usuários. A microfibra de polipropileno não influencia na resistência mecânica do concreto e melhora a durabilidade. Exemplo da fibra de polipropileno utilizada pode ser observada à direita na Figura 30.

Figura 30 - Fibras de polipropileno à direita utilizadas nos traços de concreto projetado.

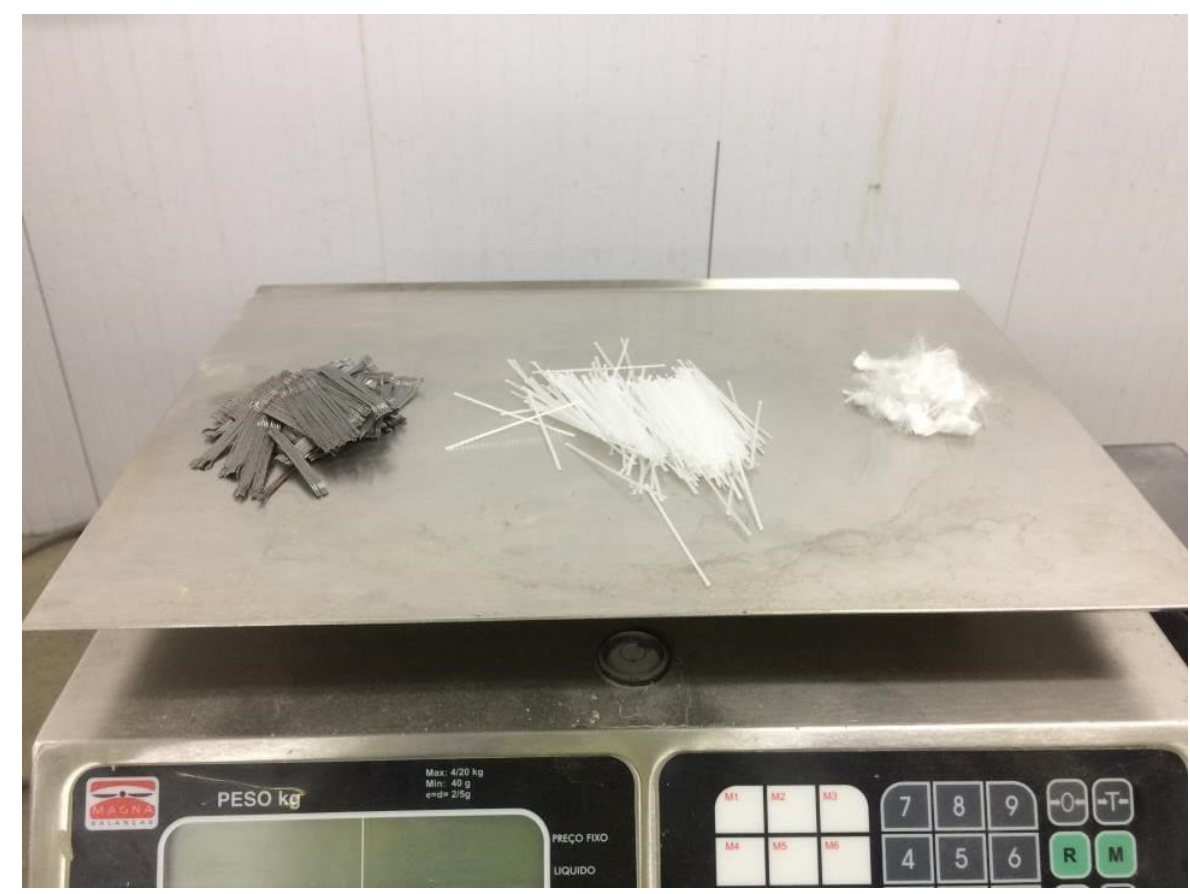

Fonte: O Autor (2019). 
O controle da espessura das camadas de concreto foi feito com o auxílio da equipe de topografia. A partir da utilização do Estação Total, se verificava as informações topográficas reais e as convergia para as informações topográficas de projeto do gabarito de cada seção transversal. Desta forma, era possível marcar com tinta, áreas de overbreaks a serem preenchidas com concreto projetado e com o auxílio de uma barra metálica cravada no maciço, se utilizava um gabarito em forma de "S", como na Figura 31, indicando até que ponto a área deveria ser concretada para coincidir com o gabarito da seção, a tornando praticamente uniforme.

Figura 31 - Gabarito em "S" indicando o limite para correção de overbreak.

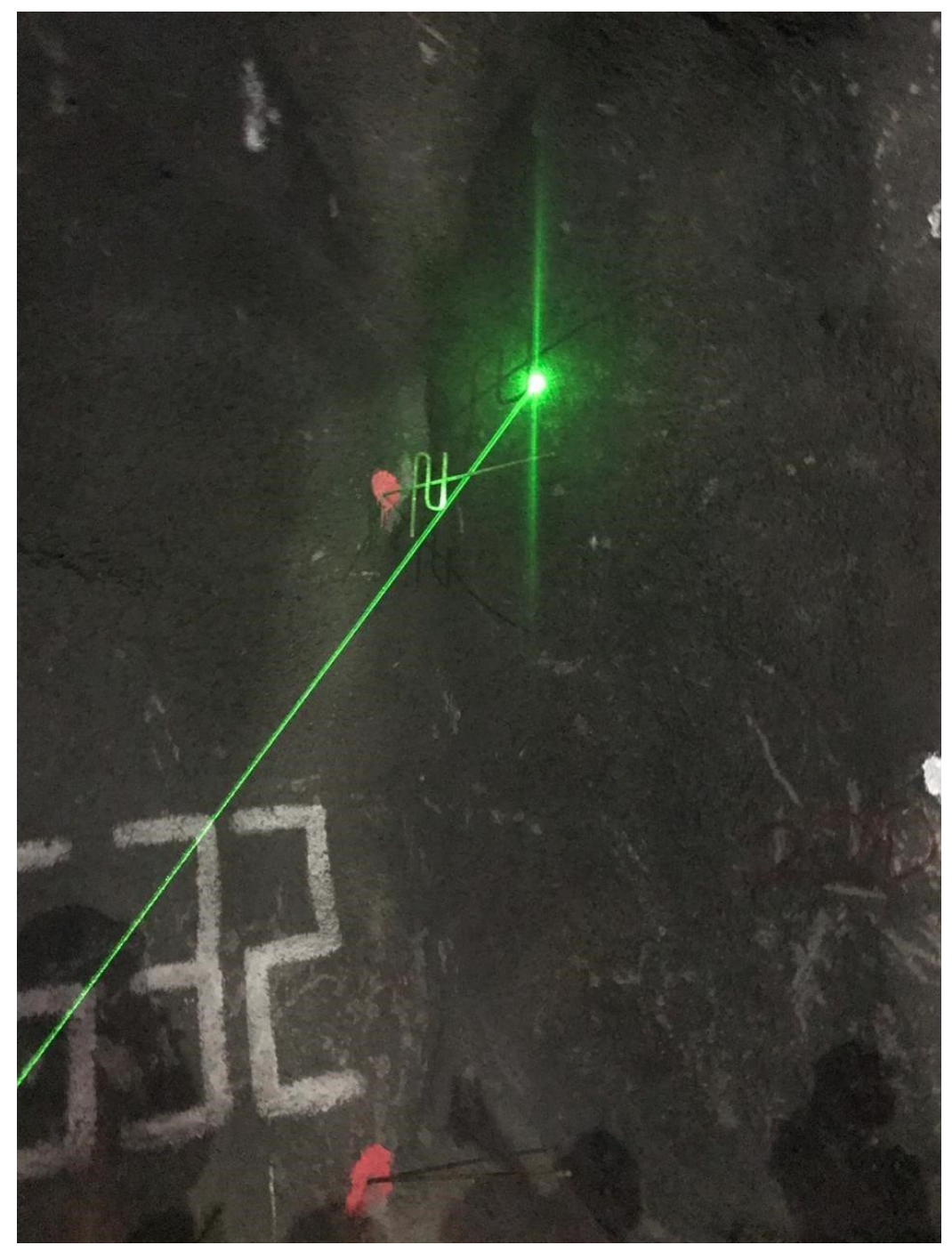

Fonte: O Autor (2019). 


\subsection{CAMBOTAS METÁLICAS}

As cambotas metálicas foram utilizadas como na Figura 32, onde se encontram classes de rochas de baixa resistência em trechos com pouca cobertura superficial do maciço. É um elemento de suporte estrutural que tem como função suportar as cargas do terreno quando o auto suporte é reduzido em conjunto com o concreto projetado. As cambotas metálicas treliçadas apresentavam formato de arco e acompanham a abóboda da seção do túnel, conforme a Figura 33 e funcionavam escorando parcialmente os empuxos provenientes das deformações do maciço, transferindo a carga para o piso do túnel.

Figura 32 - Trecho de túnel escavado em meia seção com a utilização de cambota metálica.

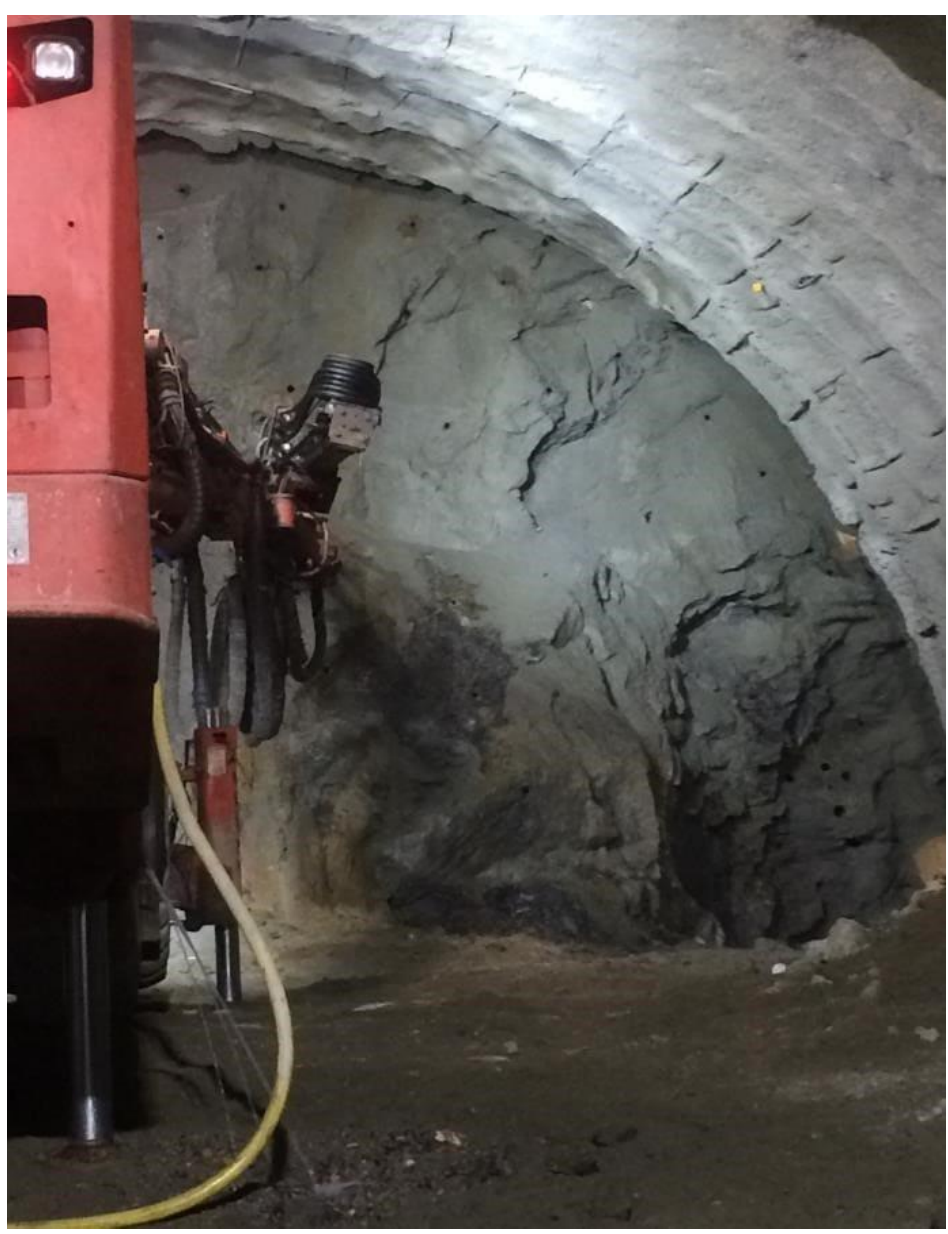

Fonte: O Autor (2019). 
Figura 33 - Detalhe do projeto de cambota treliçada.

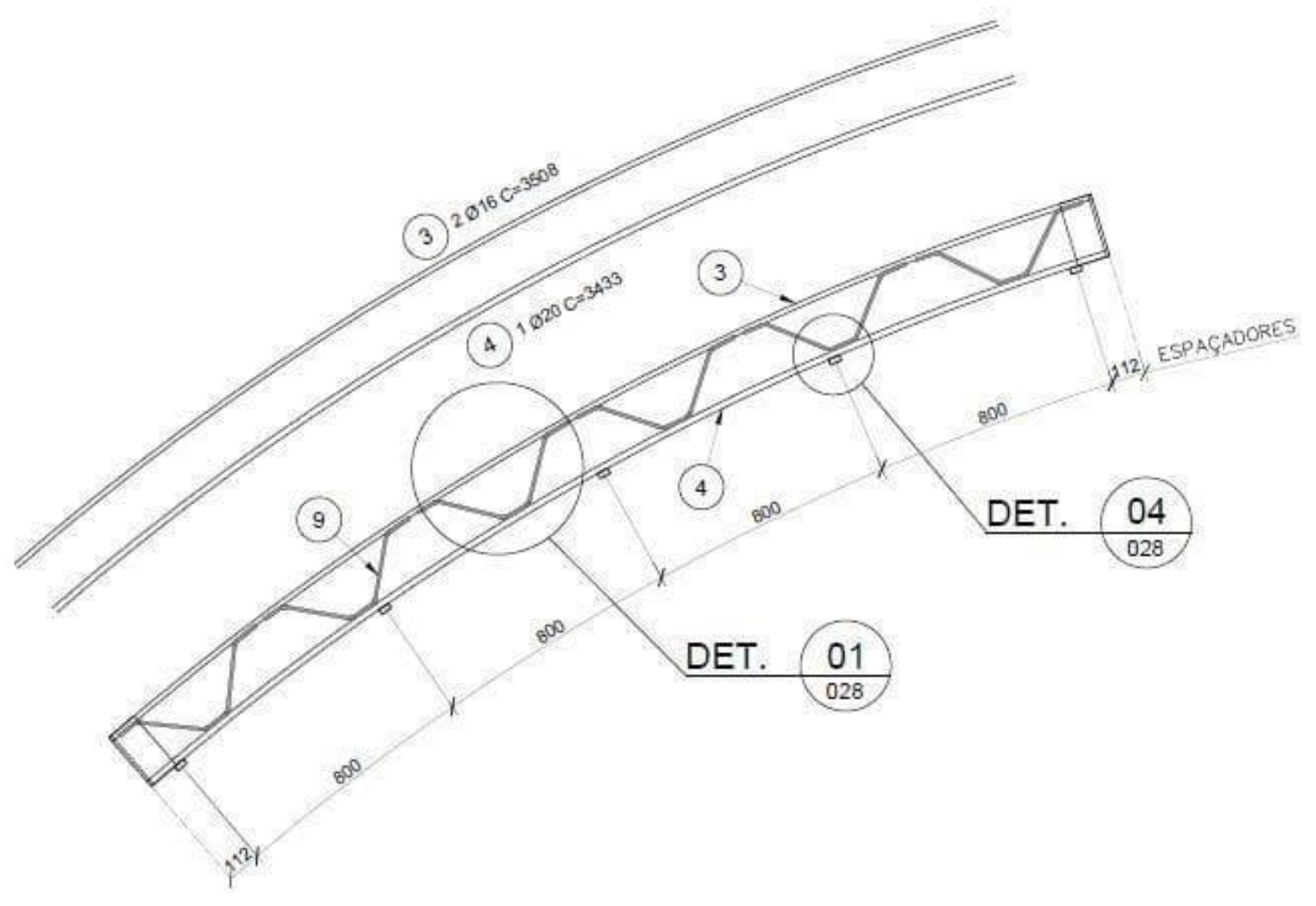

Fonte: Construtora Queiroz Galvão (2019).

\subsection{TIRANTES E ENFILAGENS}

Os tirantes têm a função de sustentação para um possível desprendimento de blocos de rochas, e criam uma zona de resistência acima da abóboda do túnel. Na obra do exemplo a inserção de tirantes foi realizada em todos os túneis e em todos trechos, como garantia de suporte. A execução dos furos pode ser observada na Figura 34.

Com o auxílio do Estação Total, o serviço de topografia marcava com tinta o local exato onde os tirantes deveriam ser colocados de acordo com informações de projeto. A seguir o Jumbo executava os furos. A quantidade e espaçamento dos tirantes variava de acordo com a classificação do maciço em cada trecho, mas o processo de execução era igual em todos os casos. Após a furação, os tirantes eram introduzidos e fixados ao maciço com o auxílio de uma resina. 
Figura 34 - Furação para aplicação de tirantes pelo Jumbo.

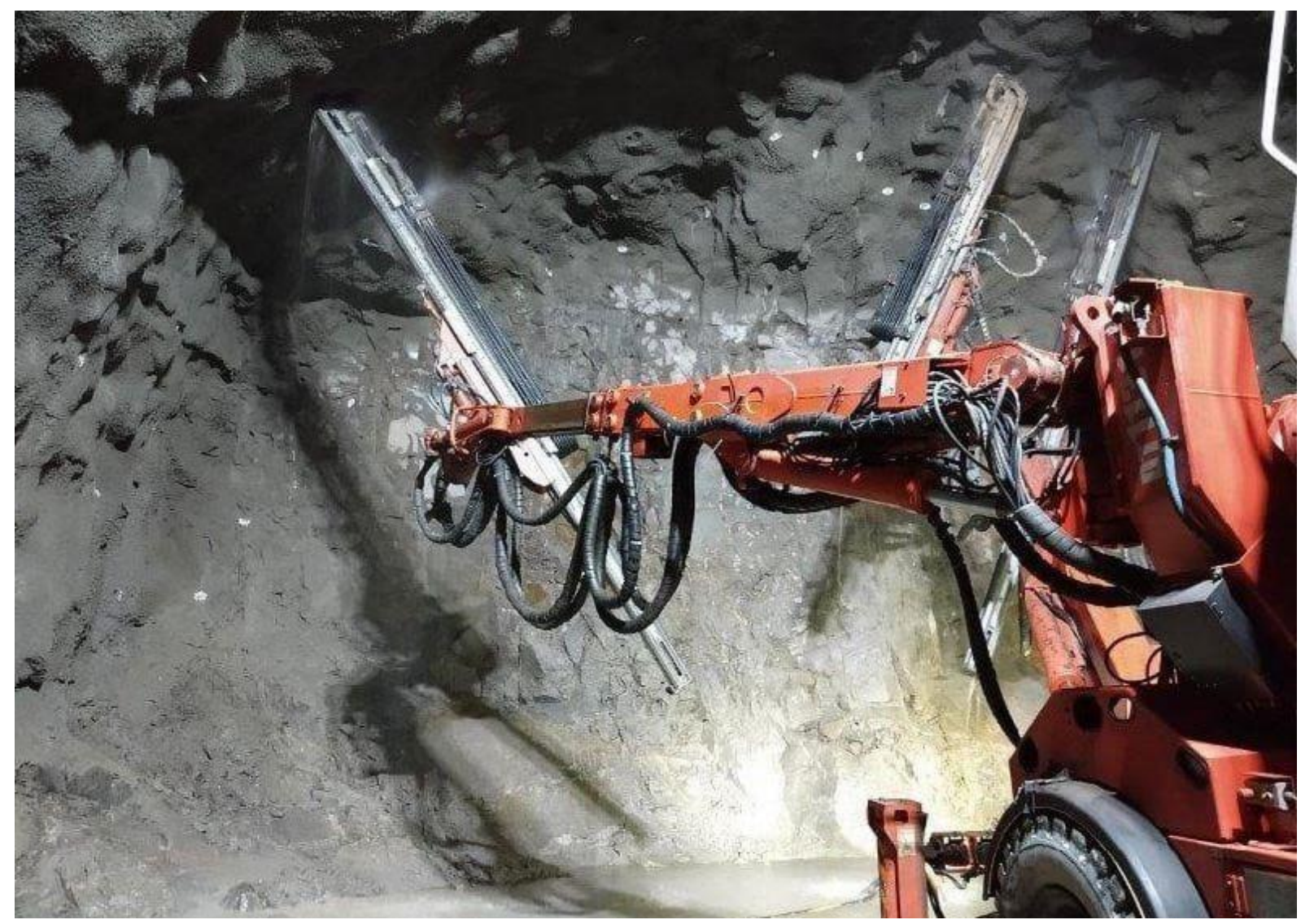

Fonte: Construtora Queiroz Galvão (2019).

A enfilagem tubular injetada de aço constitui outro elemento de suporte, mas que não foi utilizado em todos os túneis desta obra. Os trechos que possuíam uma classificação rochosa de baixa resistência, ou com presença de solo, ganharam esse tratamento extra, ou seja, as enfilagens eram introduzidas para gerar suporte no trecho seguinte, antes da detonação da seção. Ocas com válvulas manchetes, possibilitavam a introdução de argamassa no maciço com alta pressão, criando uma camada capaz de suportar o peso acima de sua estrutura.

$\mathrm{Na}$ Figura 35, é possível visualizar as enfilagens introduzidas antes da próxima detonação no ciclo de escavação (trecho azul), com detalhe também para marchavantes (trecho vermelho), elementos similares aos tirantes, mas que reforçavam a zona de resistência entre as sessões de enfilagem, além do núcleo de 
rocha deixado ao centro da seção (trecho verde), que ajudava na sustentação da mesma na execução de tratamento e suporte preliminares.

Figura 35 - Detalhe de seção com suporte executado.

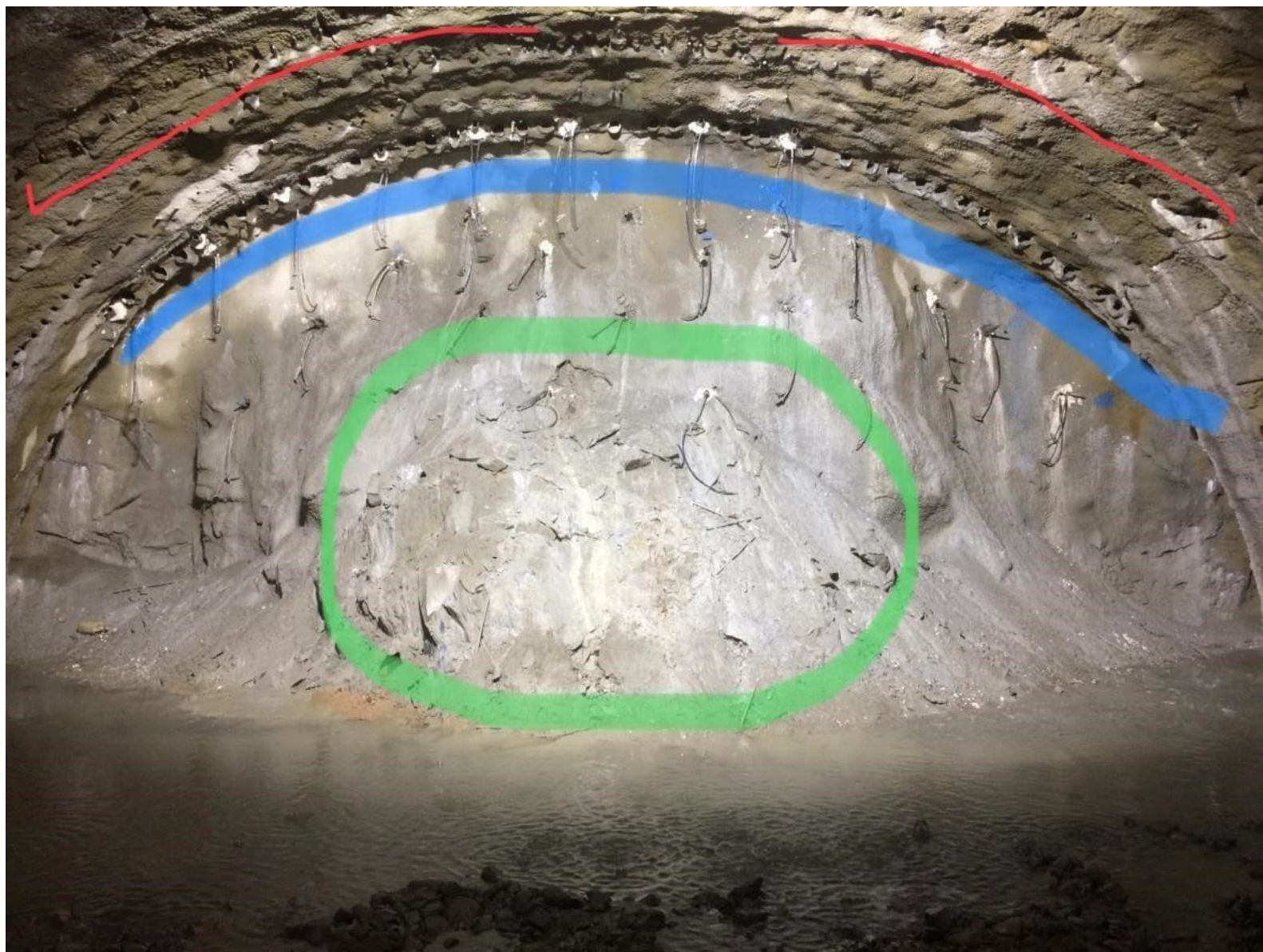

Fonte: O Autor (2019).

\subsection{REUTILIZAÇÃO DO MATERIAL DE ESCAVAÇÃO}

Considerando a extensão total dos túneis e sua grande área de seção transversal, o volume de material a ser escavado era muito grande, a previsão era de 1,9 milhões de $\mathrm{m}^{3}$ de material proveniente das escavações. Este material foi reutilizado na produção de agregados para os diferentes traços de concreto utilizados na obra e para serviços de pavimentação e terraplenagem. Amostras do material retirado foi analisada com frequência para testes e ensaios de resistência e abrasão, a fim de verificar a qualidade do material para utilização como agregado. Isso permitiu grande 
economia na produção de concreto e possibilitou a amortização do Diagrama de Brückner, uma vez que esses materiais não precisaram de bota fora. A figura 36 mostra dois britadores industriais instalados no canteiro de obras.

Figura 36 - Britador industrial no canteiro de obras.

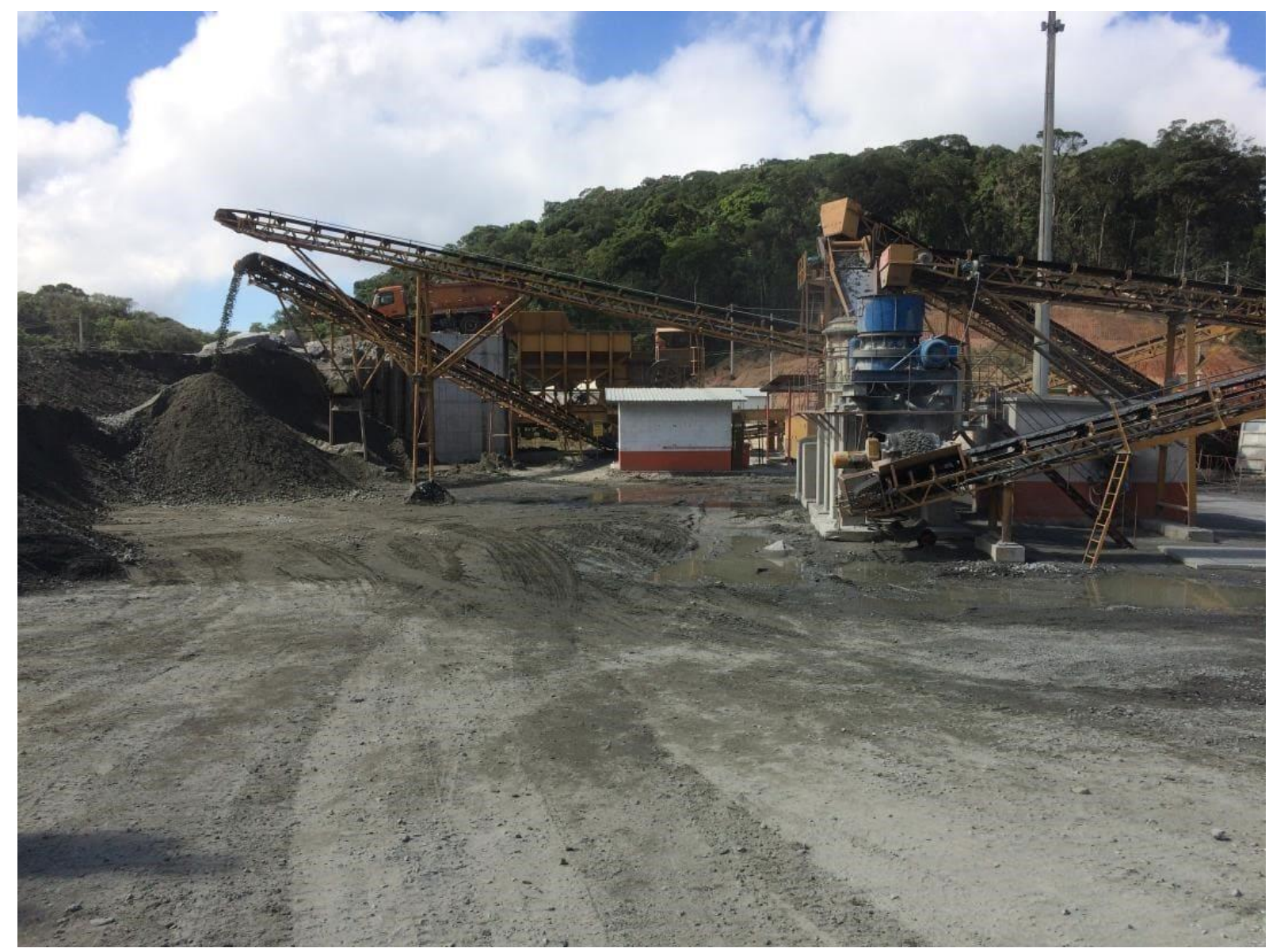

Fonte: O Autor (2019).

\subsection{REAPROVEITAMENTO DE ÁGUA}

A obra está situada no Parque Estadual da Serra do Mar, sendo a maior unidade de preservação da Mata Atlântica existente, então o aspecto ambiental foi de grande importância. Os maciços rochosos possuíam uma grande quantidade de água confinada e o Jumbo também trabalhava com jatos de água de alta pressão, o que acarreta um grande consumo. Para o reaproveitamento da água, foram instaladas duas estações de tratamento de água, como mostrado na Figura 37. 
O detalhe é que, em algum momento, o túnel terminaria de ser escavado, além disso, o volume de água oriundo dos maciços era maior do que o utilizado pelo equipamento. Ou seja, o volume de água reutilizado era menor do que o volume de água captado. Por isso, a água tratada chegou a um nível de 100\% de potabilidade, algo superior às próprias empresas distribuidoras de água potável na região sudeste, parâmetros inéditos na construção civil. Dessa forma, a água possuía condições de ser devolvida ao meio ambiente, em rios próximos da região, sem contaminar seu meio.

Figura 37 - Estação de Tratamento de Água em frente ao emboque São José do túnel T1.

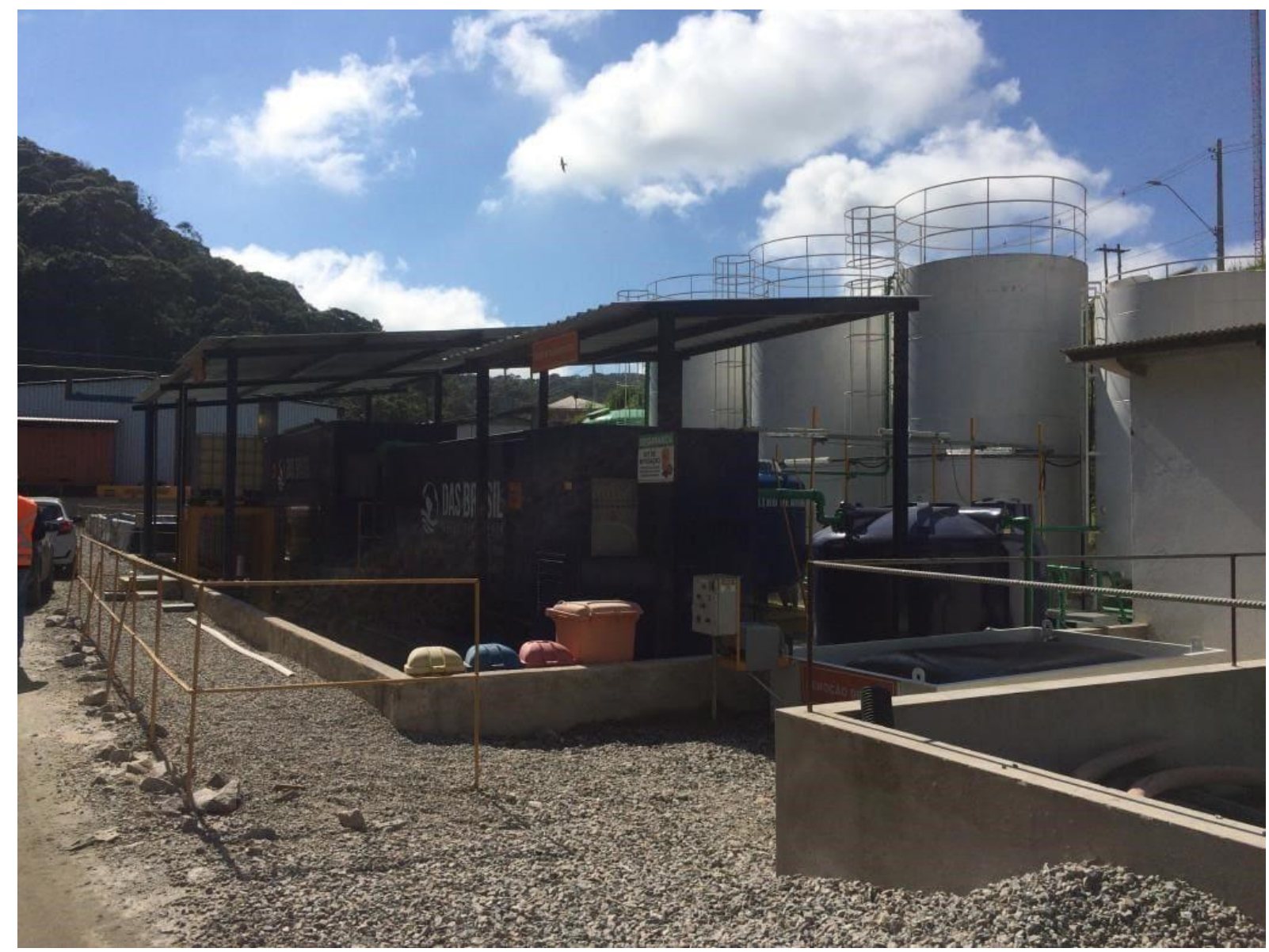

Fonte: O Autor (2019). 


\section{CONCLUSÃO}

O crescimento econômico e populacional traz a necessidade da implementação de novos caminhos para mobilidade humana. Os caminhos subterrâneos são uma opção importante quando a superfície está saturada ou apresenta dificuldades topográficas. O NATM é um método consolidado e é uma boa alternativa para execução de túneis, devido a versatilidade e conseguir lidar com condições geológicas muito heterogêneas. Por não se tratar de um método mecanizado, reduz bastante o custo de escavação e como não possui dimensões de seção fixa, pode se adequar ao formato necessário.

O avanço tecnológico tem tornado as questões de segurança cada vez mais robustas, propiciando maior conforto e redução de riscos de desmoronamento dos maciços, bem como o controle preciso dos abalos sísmicos da região. O NATM é um método que utiliza mão de obra em conjunto com recursos tecnológicos, permitindo um custo total competitivo frente à complexidade encontrada nas escavações.

O processo de escavação de túneis é complexo e o NATM tem muitos detalhes, a proposta deste artigo foi descrever de forma compacta, mas com bom grau de detalhamento as principais características do método, bem como apresentar um exemplo prático no Brasil, que ajudará a consolidar a absorção do conhecimento teórico.

\section{REFERÊNCIAS}

AMARAL FILHO, Epaminondas Melo do. Tecnologia de Concreto Aplicado a Revestimento de Túneis. 1 Simpósio sobre Túneis Urbanos, TURB, ABGE, São Paulo, 1995.

ASSIS, A. P., 2002. Mecânica das Rochas: obras subterrâneas - Apostila. 2002. Departamento de Engenharia Civil, Universidade de Brasília, Brasília, Distrito Federal.

BARTON, N.; LIEN, R.; LUNDE, J; 1974. Engineering Classification of Rock Masses for the design of tunnel support. Rock Mechanics, v. 6, n. 4, p. 189-236. 
FRANCO, Fernando, 2014. Escavações de Túneis em Rocha pelo Método NATM (New Austrian Tunneling Method). Projeto de Graduação da Universidade Federal de Minas Gerais, MG.

FOSSEN, H. Structural Geology. $1^{\text {a }}$ ed. Norway. 2012.

GERALDI, José Lúcio, 2011. O ABC das Escavações de Rocha. Editora Interciência, Rio de Janeiro.

GUIMARÃES FILHO, J. D.; GUIMARÃES NETO, J.D. 1995. Equipamentos de Suporte. In: Simpósio sobre Túneis Urbanos, 1, São Paulo. Anais, São Paulo: ABGE/CBT. p. 149-162

HOEK, E. 1983. Strengh of joited rock masses: rankine lecture. Geotechnique, v. 33, n. 3, p. 187-223.

HOEK, E. 1994. Strength of rock and rock masses. IRSM News Journal, v. 2, n. 2, p. 4-16.

HOEK, E.; BROWN, E.T. Underground excavation in rock. The Institution of Mining and Metallurgy. 1982.

HOEK, E.; KAISER, P.K. e BAWDEN, W.F. 1997. Support of underground excavations in hard rock. Rotterdam, A.A. Balkema.

MONTICELI, J. J.; TRESSOLDI, M. Diretrizes para descrição de sondagens: 1a tentativa. Associação Brasileira de Geologia de Engenharia e Ambiental. São Paulo. 2013.

MASCARENHAS, André, 2014. Estudo de caso: escavação e tratamento para emboque de túnel em rocha utilizando o método NATM - Região Portuária, Centro do Rio de Janeiro. Projeto de Graduação da Escola Politécnica da Universidade Federal do Rio de Janeiro, RJ. 
MOREIRA, Carlos Manuel da Cruz. Túneis: uma herança ancestral rumo ao futuro. A obra nasce: Revista de Arquitetura da Universidade Fernando Pessoa. Porto, Portugal, n.3, 2006.

OLIVEIRA, Antônio Manoel; MONTICELI, João Jerônimo. 2018. Geologia de Engenharia e Ambiental, volume 2 e 3. ABGE - Associação Brasileira de Geologia de Engenharia e Ambiental. São Paulo.

RABCEWICZ, L. V. Tunnel under Alps uses new, cost-saving lining method. Civil Engineering - ASCE, 1975.

RIBEIRO NETO, F. Segurança, Ruptura e Colapso de Túneis Urbanos em NATM. 1999, 171 p. Dissertação (Mestre em Engenharia) - Escola Politécnica da Universidade de São Paulo, São Paulo.

RICCI, M; PETRI, S. Princípios de Aerofotogrametria e Interpretação Geológica. $1^{\underline{a}}$ ed. São Paulo. 226p. 1965.

ROCHA, Hugo Cássio. Panorama do Mercado Brasileiro de Túneis: Passado, presente e futuro. Anais do 54ํㅡㄹ Congresso Brasileiro de Concreto, CBC 2012. Maceió, Alagoas.

SAUER, G; MERGELSBERG, W. 2003 Tunneling... and beyond. Herdon: Sauer Corp.

TEIXEIRA, A.H. 1995. Tratamento de maciços de solos. In: Simpósio sobre Túneis Urbanos, 1, São Paulo. Anais, São Paulo: ABGE/CBT. p. 163-182.

TRAVAGIN, Vinicius Bernardino. Subsídios para escolha do método construtivo de túneis, 2012. Tese de Mestrado em Engenharia Civil - Universidade Tecnológica Federal do Paraná, Curitiba, 2012.

Enviado: Março, 2020.

Aprovado: Maio, 2020. 